\title{
معايير مقترحة لتقويم أداع معلمات التربية الفنية بالتعليم العام بالمملكة العربية في ضوء معايير الجودة
}

\author{
إعــــــداد \\ د. أميرة عبد الرحمن منير الدين \\ أستاذ المناهج وطرق تدريس التربية الفنية المشارك التركين \\ بجامعة أم القرى
}

مجلة الاراسات التربوية والاسانية ــ كلية التربية ـ جامعة دمنهور المجلد الخامس العدد(4) - الجزء الثالث- لسنة 2013 
معايير مقترحة لتقويم أداء معلمات الثربية الفنية بالتعليم العام دــأميرة عبد الرحمن منير الدين 
معايير مقترحة لتقويم أداء معلمات التزبية الفنية بالتعليم العام بالمملكة العربية

$$
\text { في ضوء معاييز الجودة }
$$

د. أميرة عبد الرحمن منير الدين

$$
\text { ملخص البحث: }
$$

"إلقاء الضوء على مفاهيم الجودة،و الجودة الشاملة، و الجودة الشاملة في التعليم، وفو ائد ضبط الجودة في مؤسسات التعليم، ومعايير الجودة. الإشارة إلى المصادر التي اشتقت منها المعايير المقترحة لجودة أداء معلم التزبية الفنية في التعليم العام.

- إعداد قائمة جدولية للمعايير المقترحة لجودة أداء معلمي التزبية الفنية في التعليم العام بالمملكة العربية السعودية تشمل المجال و المعيار الأدائي

$$
\text { و المؤشرات. }
$$

• بيان نسبة تو افر المعابير المقترحة لجودة أداء معلمات التربية الفنية في التعليم العام بالمملكة العربية السعودية. نتائجج الار اسةة: على ضوء تساؤلات و أهداف ومنهجية الدر اســة و أدو اتهــا جاءت النتائج كما بلي • تم الثعرف على الجودة، والجودة الشاملة، و الجودة الشاملة في التعليم بصفة خاصة. • تم إعداد وتقديم قائمة جدولية للمعايير المقترحة لجودة أداء معلمي التربية الفنية في التعليم العام بالمملكة العربية السعودية نشمل المجال و المعيار

$$
\text { الأدائي و المؤشر ات. }
$$

تم الوصول إلى أن هناك انخفاضًا ملحوظاً في الأداء المهني لمعلمات التربية الفنية بالتعليم العام بالمملكة العربية السعودية في ضوء معايير جودة أداء المعلم

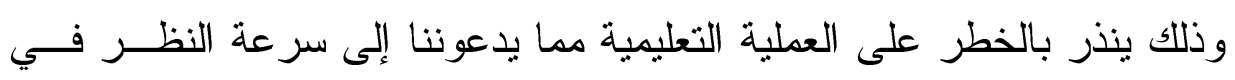




$$
\text { الثاملة. }
$$




\section{Research Title:}

\section{Research Summary}

Proposed Standards to Evaluate Performance of Art Education Female Teachers in Public Education in Kingdom of Saudi Arabia in Light of Quality Standards.

\section{Preparad By:}

Dr. Amira Abdel Rahman Mohamed Ali Munir El Din

Associate Professor in of Art Education Department, Faculty of Education, Umm Al-Qura University, General Specialty: Curricula and teaching methods, Accurate specialty: Curricula and teaching methods of Art Education.

Research Objectives: The research aims at the following:

1.Highlight the quality, the total quality and the total quality in Education in particular, the benefls of adjusting in Establional Establishments, and quality standards.

2.Indicate the sources from which the proposed standards of performance quality of Art Education teacher in Public Education are derived.

3.Prepare and provide tabular list for the proposed standards of performance quality of Art Education teachers in Public Education in Kingdom of Saudi Arabia including the field, the performance standard and Indicators.

4.Clarify the extent of availability for performance quality of Art Education female teachers in Public Education in Kingdom of Saudi Arabia.

Research Results: Based on questions, objectives, methodology and tools of the study, the results come as follows:

1.The quality, the total quality and the total quality in Education in particular have been identified.

2.A tabular list for the proposed standards of performance quality of Art Education teachers in Public Education in Kingdom of Saudi Arabia including the field, the performance standard and Indicators have been prepared and provided.

3.It was found that there is a significant decline in the professional performance of Art Education female teachers in Public Education in Kingdom of Saudi Arabia in the light of the teacher's quality performance an $d$ that is alarming to the educational process, the matter which obligates us to speedily consider the programs of preparing the Art Education teachers and developing them in line with the total quality standards. 
المقدمة وتحديد مشكلة الدر اسة :

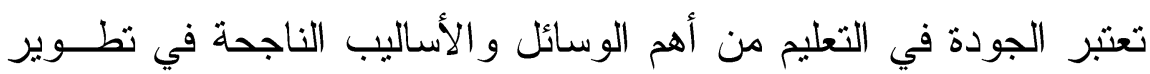

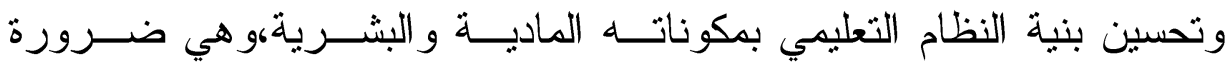

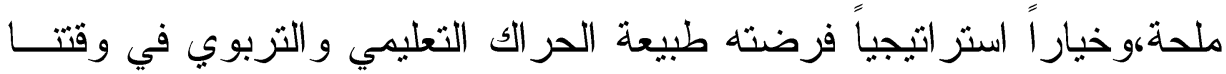
الحاضر، وفي المجال التربوي على وجه التحديد بدأ الحديث عن مفاهيم الجودة

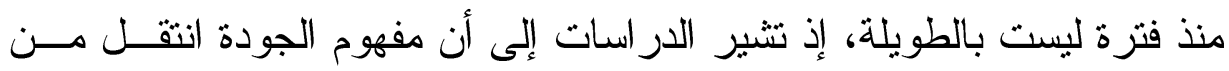

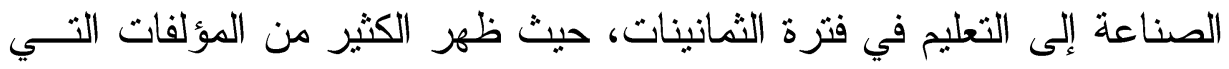

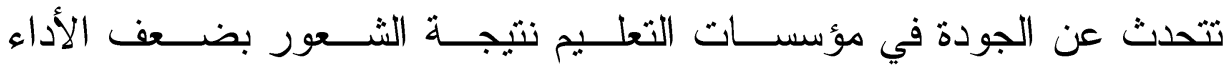

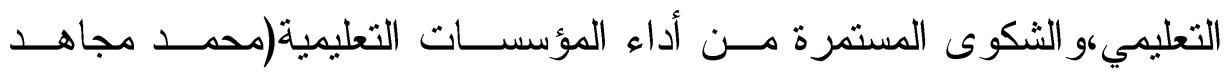
و المتولي بدير،2006م، ص22).

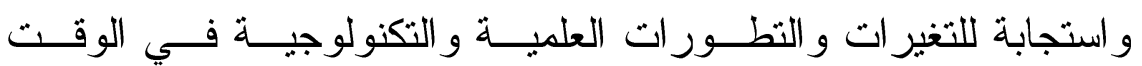
الحالي،وما صاحبها من منافسة حضارية، أكدت على التميز كضرورة ملحسـة،

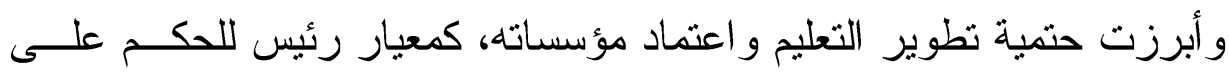

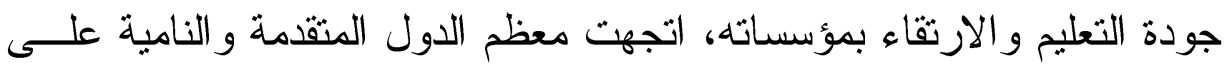

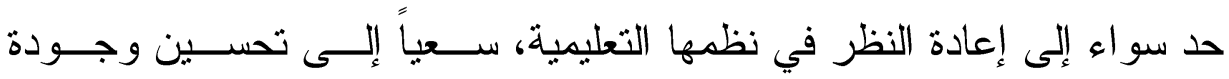

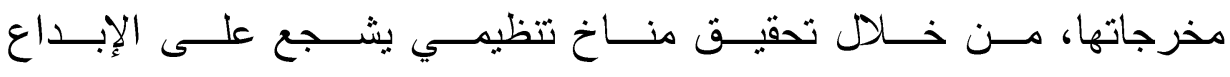

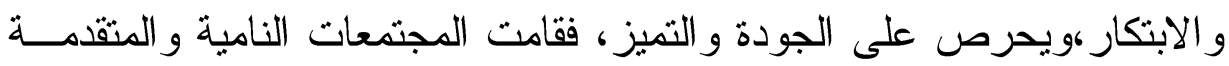

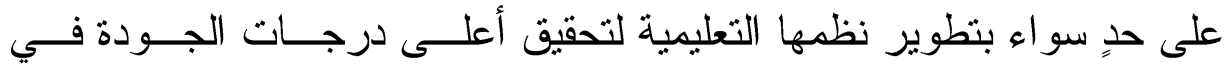
المخرج التعليمي، بما يفي باحتياجات الحاضر ويتلاعم مع معطيات المستقبل،

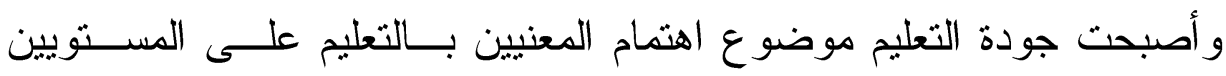

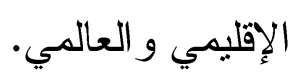

ومن الدول التي أولت اهنمام و عناية خاصة بــالتعليم و أنظمتــه المملكـــة

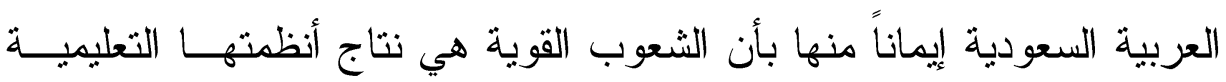

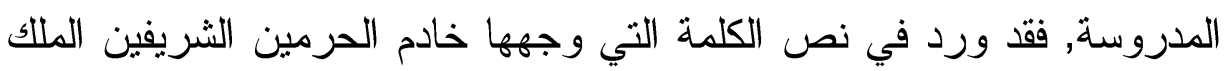

$$
\text { doi : } 10.12816 / 0004231
$$


عبداله بن عبدا لعزيز آل سعود حفظه الله لأبنائه المو اطنين"إن تتميــة القــوى

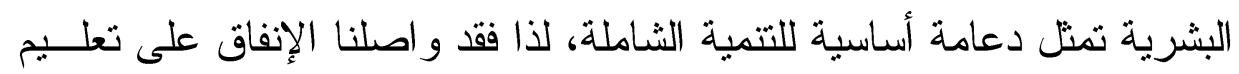

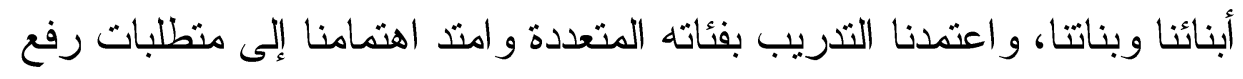

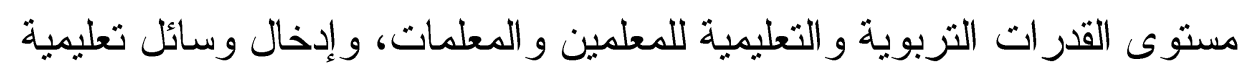

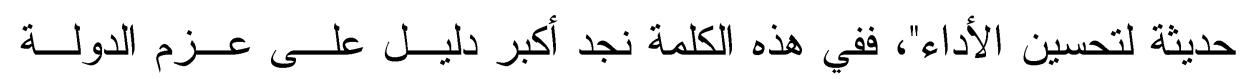

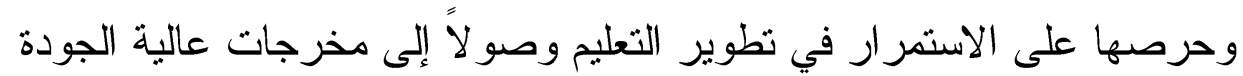

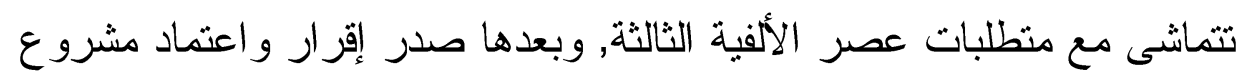

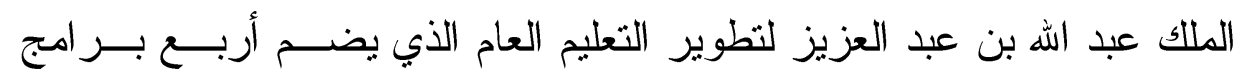

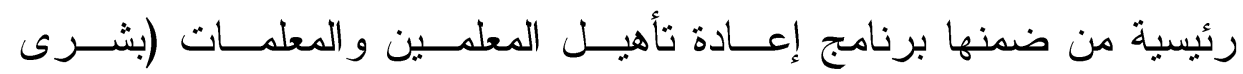

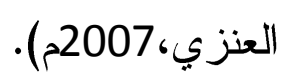

وحيث إن الارتقاء بتتمية القوى البشرية لا يتحقق إلا من خلال تعليم تثو افر

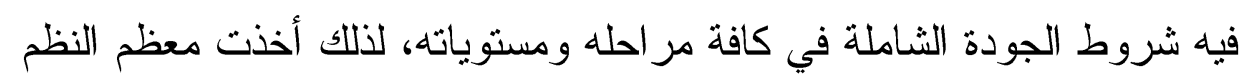

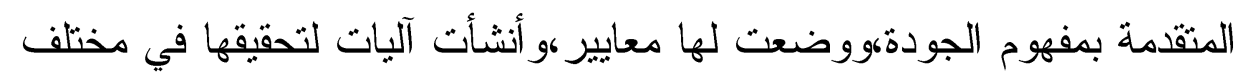
مر احل التعليم، ومن أشهرها منظومة الاعتماد أو الإجازة السائدة في نظم

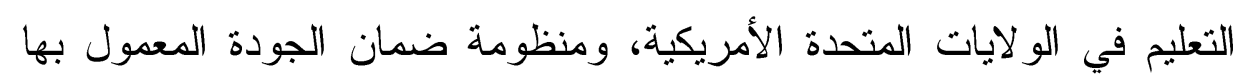
في نظم التعليم الأوربية، وخاصة المملكة المتحدة (اللجنة القومية لضمان

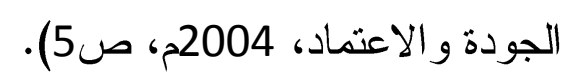
وتتطلب التتمية في ظل الجودة قبول التغيير و التعامل معه بوصفه حقيقة وله

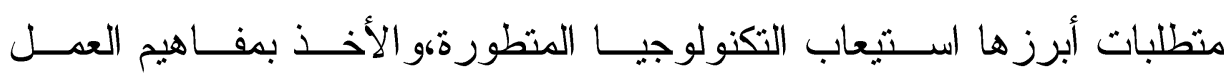

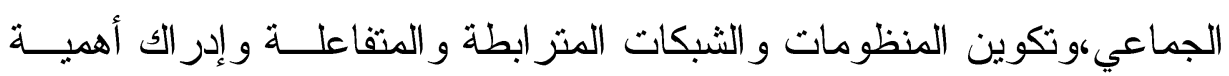

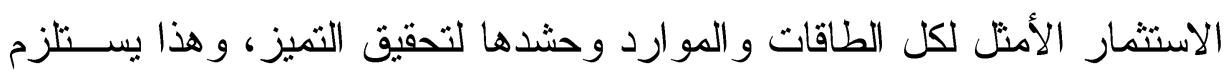

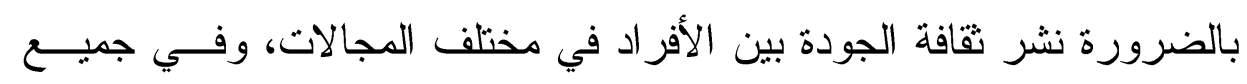

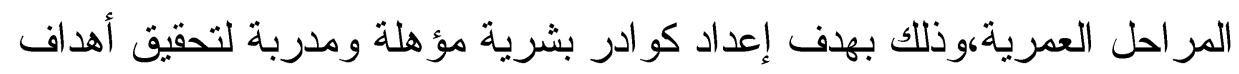

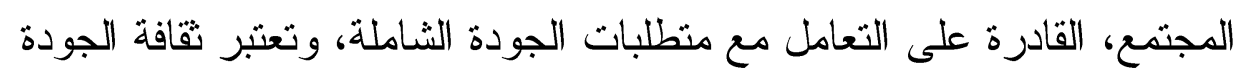


بكافة مفاهيمها ومعايير ها و آلياتها من أهم العو امل التي تفرض نفسها على و اقع تلك الفعاليات و الممارسات التزبوية المنفذة بمؤسسات التعليم بكافــة أثنــكالها

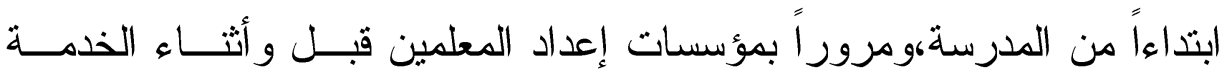
بالمعاهد و الجامعات. ومما لا شك فيه أن المعلم ركيزة أساسية ومكوناً مهماً من فئن مكونات العملية التعليمية، و النجاح في تحقيق الجودة الثاملة في التعليم يتوقف إلى حد كبير على المعلم وكفايته وقدر اته، لذلك ينبغي أن يكون هناك معسايير

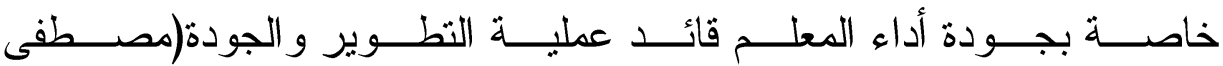
محمد،2007، 2007) - (13).

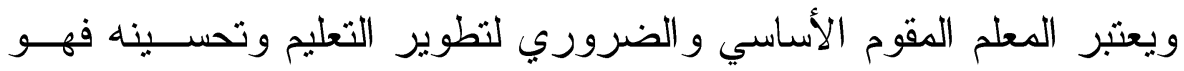

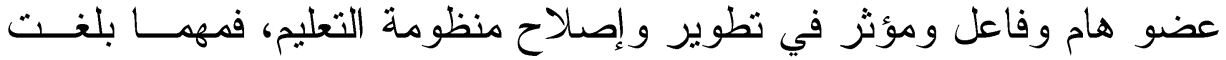

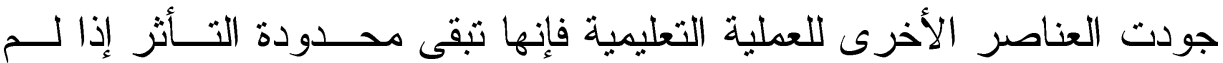

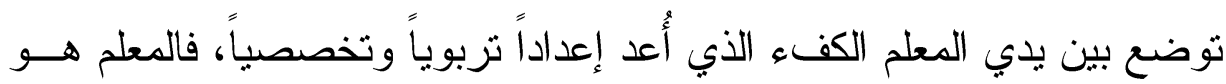

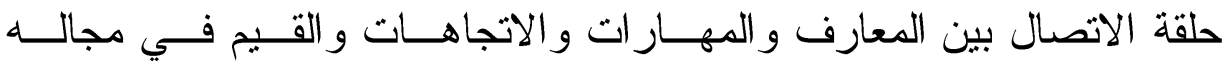
التخصصي في المنهج الدراسي، فهو الذي يقوم بعملية تفسير ونوضيح وشرح

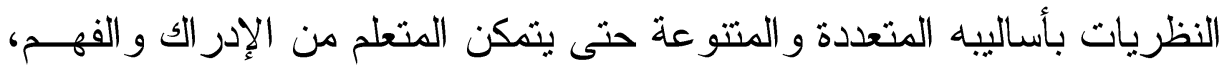

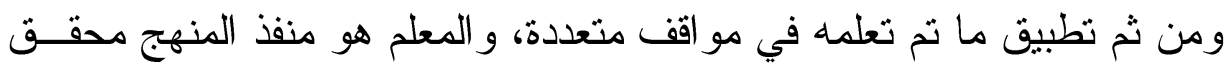
الأهداف العامة و الأهداف السلوكية، ويقوم ببناء الأنشطة التتموية المناسبة مع مع فئم

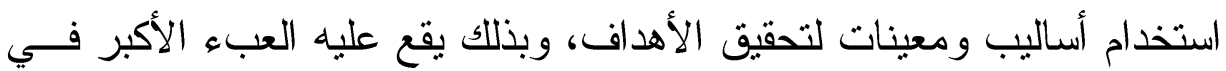
تحقيق الجودة في العملية التعليمية. ومهما امتلك المعلم من المهار ات اللازمة لقيامه بعمله فإنه مطالب بتجديدها وتظويرها و السعي وراء كل جديد خاصة ما يرتبط بتتمية مهار اته التدريسية،وفي سعيه لاكتساب مهار ات ينتج عنها تدريس جيد ومنميز يؤدي مئي إلى تحقيق جودة في نوعية التعليم، و على هذا فإن تجويد التعليم وتطويره يعتمد على معلم تم إعداده بشكل جيد، فقد يكون المنهج على درجة وعلى عالية من الجودة 
إلا أن تلك الجودة لا تكتمل فائدتها إذا اعتمدت على معلم غير جيد، وقد تكون الإدارة النزبوية في أوج الامتياز ولكن هذا الامتياز يعصف به معلم غير مؤهل

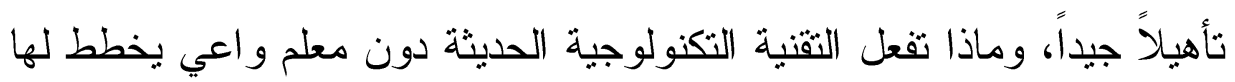

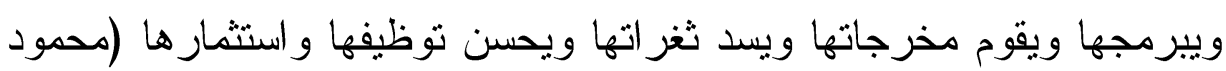

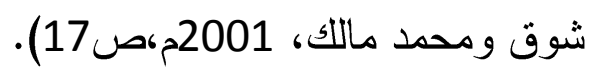
إن تقويم أداء المعلم بطرق وأساليب علمية تساعد المؤسسات التعليمية في

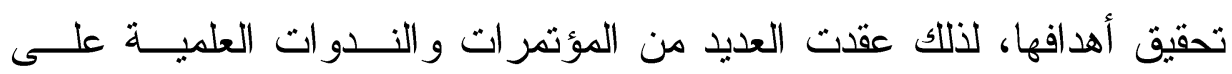
المستوى المحلي و العالمي حيث كان محورها يدور حول أدوار المعلم المتغيرة

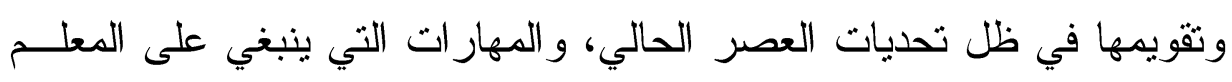
إتقانها حتى يمكنه التو افق مع متطلبات الجودة الثاملة

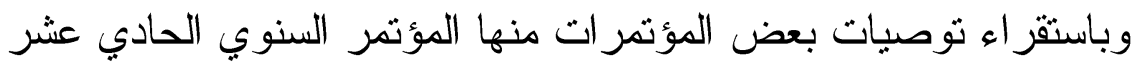

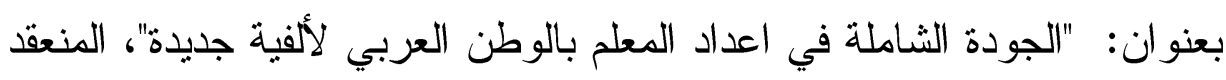

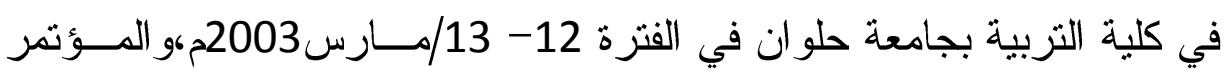

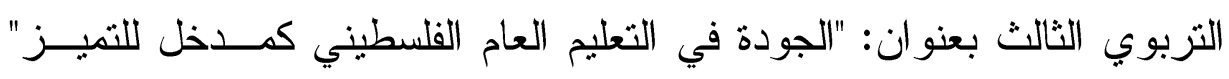

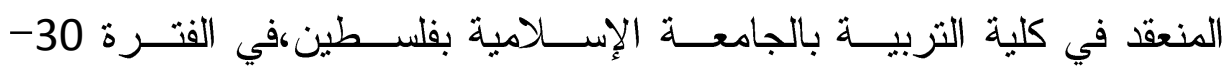

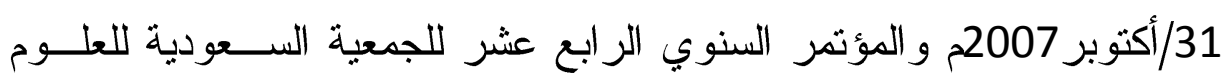

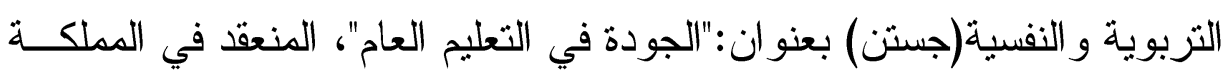

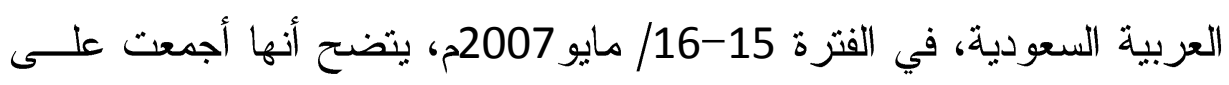

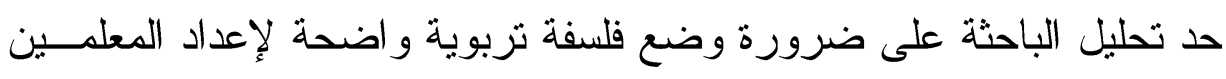
على المستويين العام و العالي،وكذلك وضع معايير للجودة توضح وبدقة الأدوار

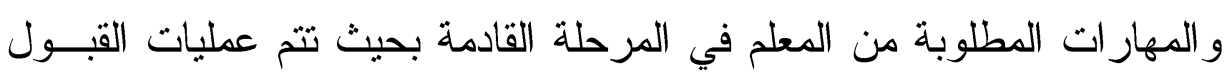

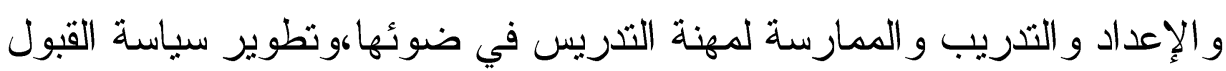

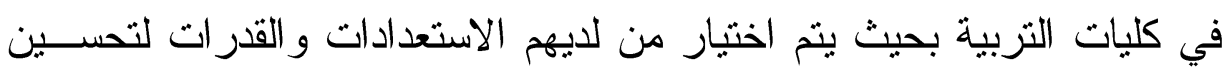

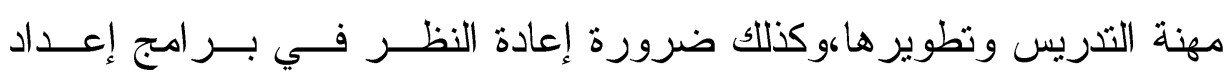


المعلمين الخاصة بالجو انب الثقافية و اللغوية و التخصصية و التزبوية، وضرورة

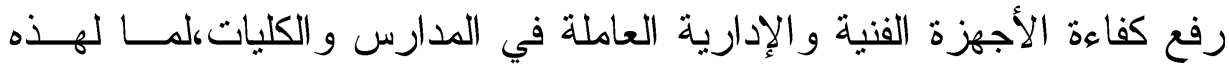

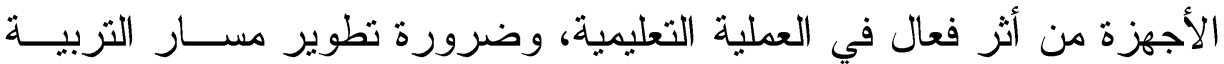

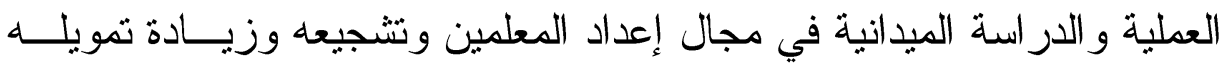
بصفته الأساس الجوهري في رفع مستوى مهنة التعليم وتدريب المعلمين أثثاء الخدمة في مدارسهم و اطلاعهم على كل جديد في تخصصاتهم المختلفة. وتخصص الثربية الفنبة تخصص له طبيعة خاصة، وله مفـــاهيم علميــة

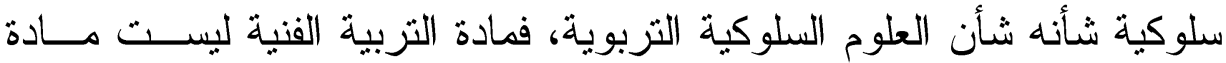

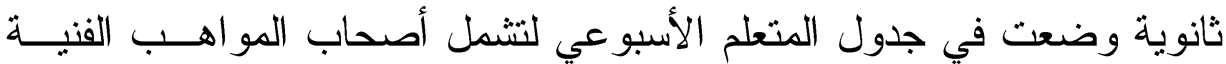

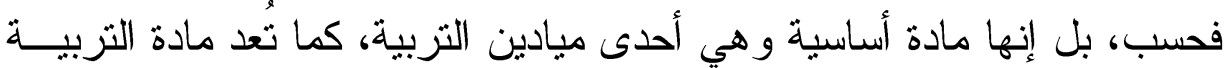

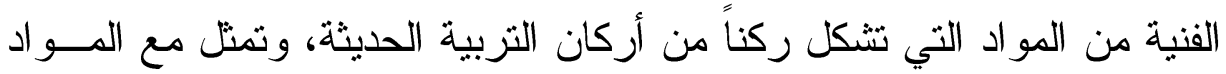

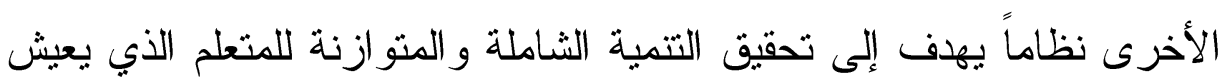
وسط التحو لات الاجتماعية المعاصرة (أحمد عايش، 2008م). لذلك كان من الضروري إعداد معلم متخصص ليقوم بتدريس هذه المادة ذات الصبغة النوعية التي لها أهدافها ومحتو اها وطرق تدريسها و أنشطتها وتقويمها، حتى تحقق ما وضع لها من أهداف في ضوء الجودة، وبناءً على ذلك فقد أكدت

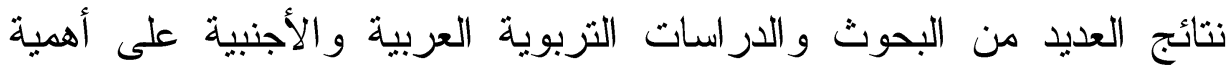
مجال التزبية الفنية، ودور معلم التزبية الفنية في تحقيق الجودة الثاملة في

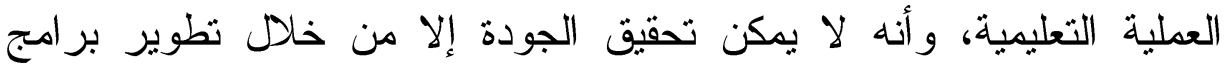

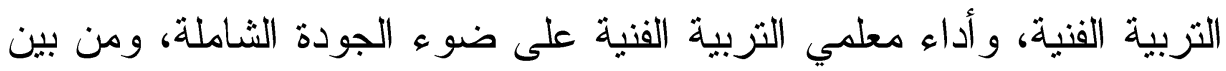
هذه البحوث و الدر اسات العربية و الأجنبية ما يلي : -در اسة كاظم جبر(2005م):استهدفت الدراسة إلى تقويم برنامج التربية الفنية

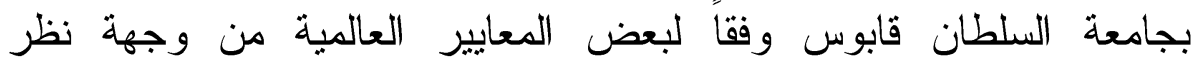
الخريجين، و أظهرت النتائج أن برنامج التربية الفنية ليس بمستوى التوقعات

$$
\text { doi : 10.12816/0004231 }
$$


من جميع الجوانب المطلوبة، وجاءت أبرز التوصيات بإعادة النظر في بر امج الإعداد بكليات النزبية.

كر اسة ايمان المريعي(2007م):استهدفت الدراسة تحديد معايير تقويم أداء طالبات التدريب الميداني المختصات في التربية الفنية بجامعة سعود بالرياض في ضوء مطالب الأداء الخاصة بمعلمة التزبية الفنية باستخدام اسلوب دلفاي،وقد نوصلت الدراسة إلى تحديد قائمة من المعايير لتقويم أداء

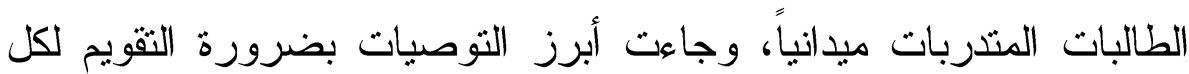
المؤسسات النربوية بأنو اعها وفقاً لمعايير الجودة.

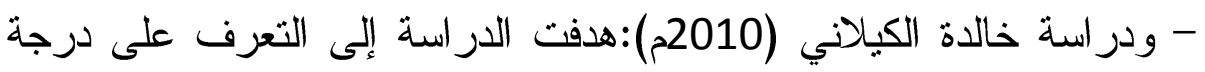
توافق محتوى برنامج إعداد معلمي الثربية الفنية في الجامعة الهاشمية ومعايير بر امج إعداد معلم التزبية الفنية للرابطة الوطنية الأمريكية للتربية

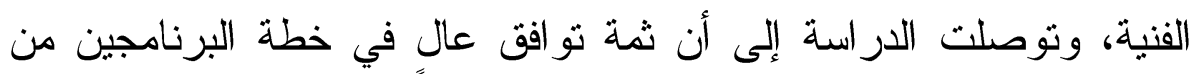

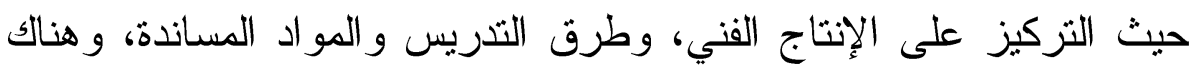

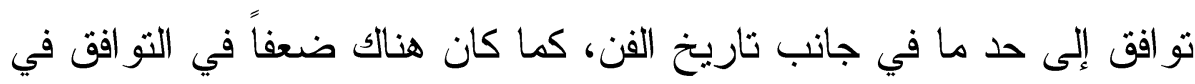

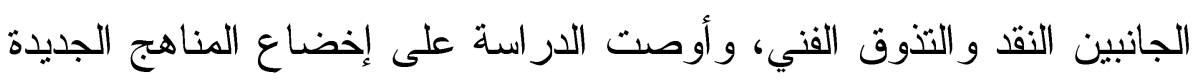
المطورة بمجالاتها الأربعة(إنتاج الفن/ تاريخ الفن/ تذوق الفن /نقد الفن)

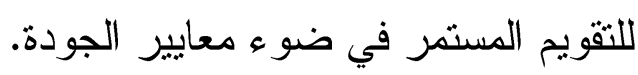

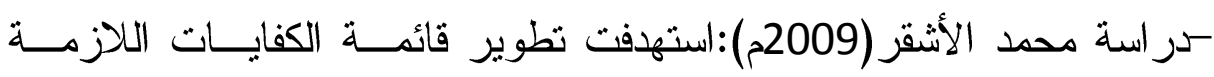
لمعلمي الفنون التشكيلية في ضوء معايير الجودة بمر احل التعليم العام بسلطنة

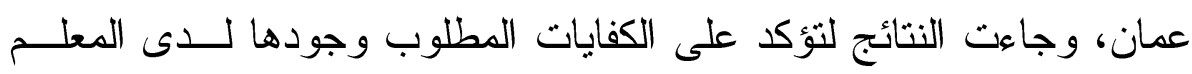
عامة ومعلم الفنون التشكيلية خاصة حيث يجب أن تكون قابلة للقياس، و أكثر ارتباطاً بالأداء و الإتقان، وتعتمد على المعارف و الخبرات السابقة، وأن يكون

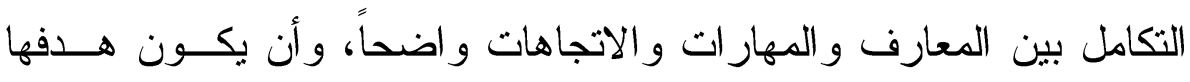
الرئيس إحداث تغيرات في سلوك المتعلمين نحو الأفضل. 
- در اسة "و ايز"(Wise,2001): استهدفت الدراسة إلى ايجاد قوة عمل التنريس عالي الجودة من خلال نظام ضمان الجودة في مهنة التشريس، والتي شملت ستة عناصر : الثهادات الدراسية، ومعايير ترخيص مزاولة المهنة، ومعايير

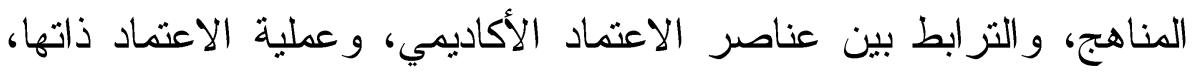
ومدارس التتمية المهنية، ومجالس المعايير على مستوى الولاية، وتوصلت التهن الار اسة إلى أن المؤسسات المعتمدة بواسطة(NCATE) تقدم معلمين أكثر ومانه كفاءة من المعلمين الذين يتخرجون من مؤسسات غير معتمدة.

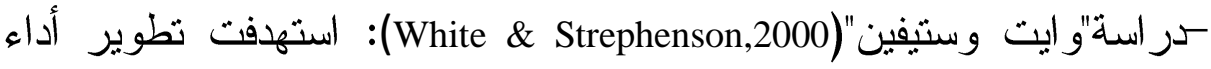
المعلم بما بحقق الجودة الثاملة في النعليم، وذلك من خلال مشاركته في الإشر اف على وضع المناهج الدراسية وممارسة الأنشطة المختلفة مع طلابه داخل المدرسة وخارجها، وأوصت الدراسة بضرورة اتاحة الفرصة للمعلم للاشتر الك في وضع المناهج التي يقوم بتدريسها و أيضا متابعة طلابه داخل وصل المدرسة وخارجها حتى تتحقق الجودة الثاملة في العملية التعليمية.

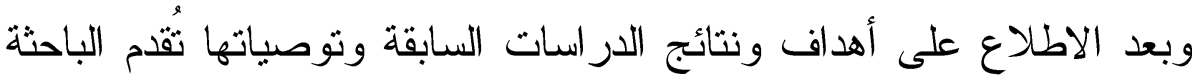
تعقيباً موجزاً يوضح الدو اعي و المبررات والأسباب التي كانت ور اءء دراتجات استها

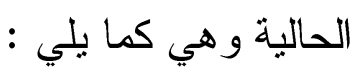
•اهتمام العديد من المؤتمرات و الندوات العلمية و البحوث و الدراسات بضرورة العمل على تحقيق الجودة الثاملة في العملية التعليمية.

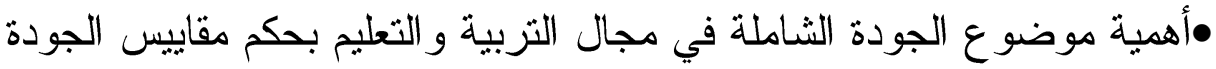
مقاييس عالمية للقياس و الاعتماد الأكاديمي للمؤسسات التعليمية.

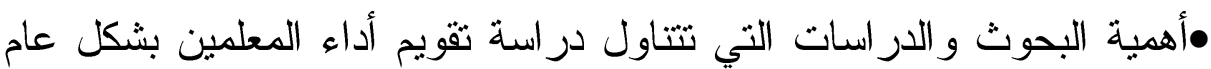
ومعلمي النزبية الفنية بصفة خاصة في ضوء معايير جودة أداء المعلم.

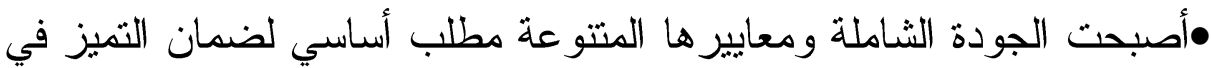
المنتج التعليمي. 
ولذلك جاءت الدراسة الحالية للوقوف على مدى تو افر معسايير جــودة أداء

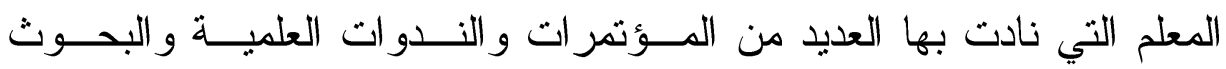
و الدراسات في ثقويم أداء معلمة التربية الفنية في التعليم العام بالمملكة العربية السعودية.

أسئلة الارسة : ت تجيب الدراسة الحالية عن التساؤلات التالية : -ما الجودة، وما الجودة الثاملة، وما الجودة الثاملة في التعليم، وما فو ائد ضبط الجودة في مؤسسات التعليم، وما معايير الجودة ؟ -ما المصادر التي اثتقت منها المعايير المقترحة لجودة أداء معلم التربية الفنية

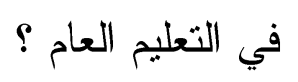
-ما المعايير المقترحة لجودة أداء معلمي التربية الفنية في التعليم العام بالمملكة العربية السعودية ؟

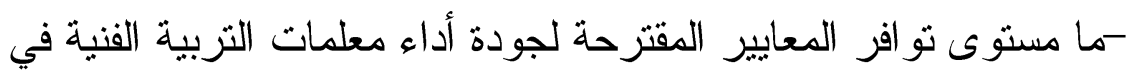
التعليم العام بالمملكة العربية السعودية ؟ أهداف الدر اسة :في ضوء تساؤلات الدر اسة جاءت أهدافها كما يلي: - إلقاء الضوء على مفاهيم الجودة، والجودة الثاملة، والجودة الثاملة في هي التعليم، وفو ائد ضبط الجودة في مؤسسات التعليم، ومعايير الجودة.

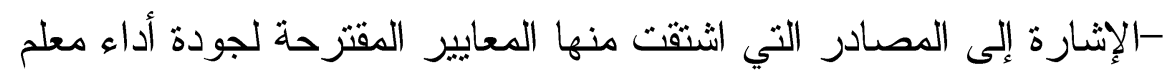
التربية الفنية في التعليم العام. -إعداد وتقديم قائمة جدولية للمعايير المقترحة لجودة أداء معلمي التربية الفنية في التعليم العام بالمملكة العربية السعودية تشمل المجال و المعيار الأدائي

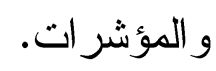
كبيان مستوى تو افر المعايير المقترحة لجودة أداء معلمات التربية الفنية في التعليم العام بالمملكة العربية السعودية. أهمية الدراسة : ترجع أهمية هذه الدراسة إلى ألى أنها : 
- تعد استجابة لتوصيات المؤتمرات و الندوات و البحوث العلمية التي أجريــــ

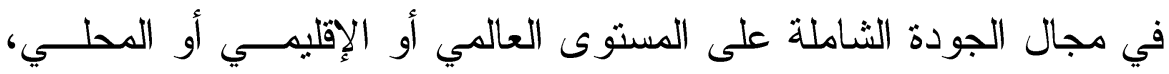

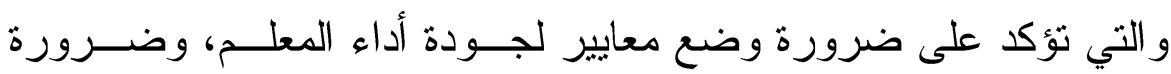
تدريب المعلمين على هذه المعايير وتضمينها في بر امج الإعداد.

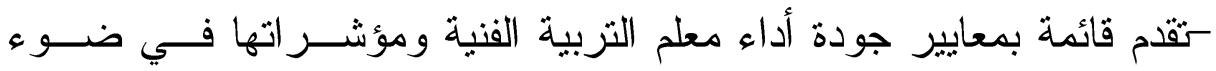

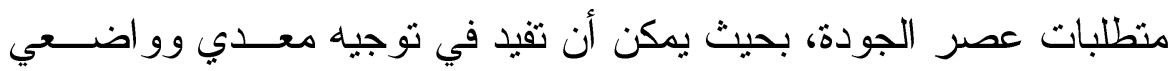
بر امج إعداد معلمي التزبية الفنية في تضمين هذه المعـايير فــي بــر امج الإعداد.

-تساعد معلمي التزبية الفنية على معرفة معايير الجودة الثاملة فــي التعلــيم و العمل على ربط أدائهم بها.

-قفيد موجهي التربية الفنية في تقويم أداء معلمي التربية الفنية بشكل علمـي لهي ومعاصر م مون.

-تقيد القائمين على التدريب بإلز ام تو افر معايير جودة أداء المعلم فـي الأداء التدريسي بمجال النزبية الفنية. حدود الدر اسة: التزمت الدر اسة الحالية بالحدود التالية :

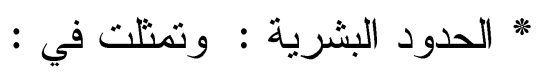

- مجتمع الدر اسة وشمل معلمات التربية الفنية في التعليم العام بالمملكة العربية السعودية. - عينة الدر اسة وهي عينة عشو ائية ممثلة لمجتمع الدراسة بلغ عـددها (30)

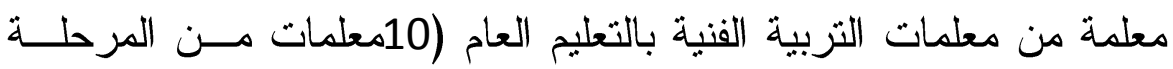

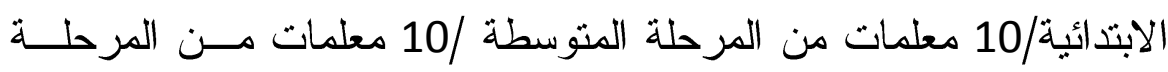
الثانوية ) من مدينة مكة المكرمة.

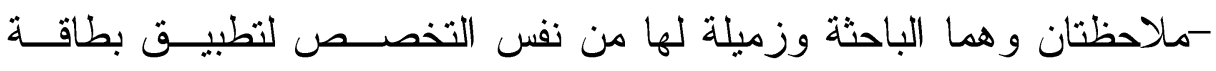
الملاحظة. 
* الحدود المكانية:بعض مدارس التعليم العام (ابتدائي، ومتوسط، وثانوي) بمدينة مكة المكرمة.

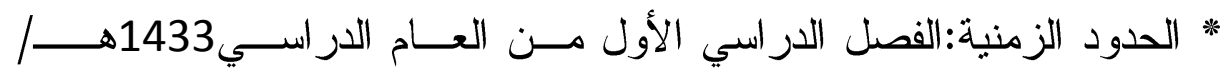
1434هـ. * الحدود الموضو عية:وشملت: موضوع الجودة و الجودة الثاملة في التعلــيم

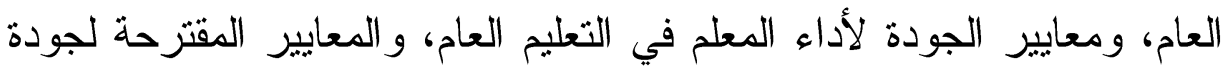

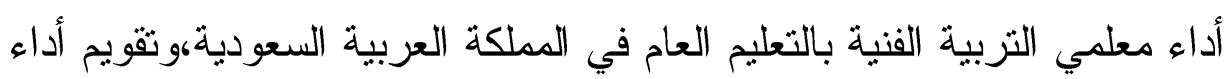

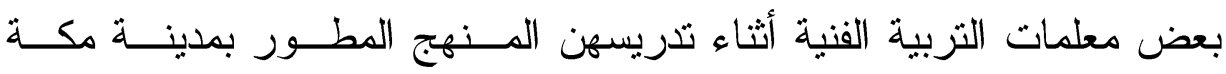
المكرمة.

منهجج الار اسة: اقتضت طبيعة الدراسة الحالية اســتخدام المــنهج الوصــفي التحليلي الذي يعتمد على دراسة الظاهرة كما توجد فــي الواقــع، ويهــتم

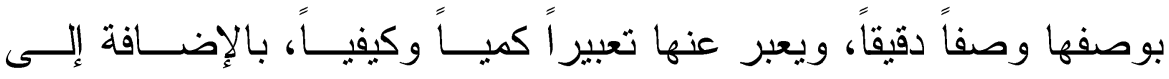

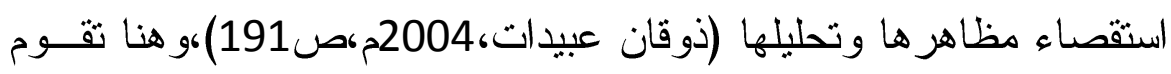
الباحثة بتحليل الوضع الر اهن لمستوى أداء بعض معلمات التزبيـــة الفنيـــة

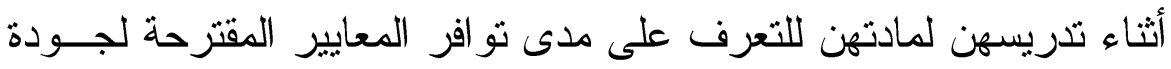

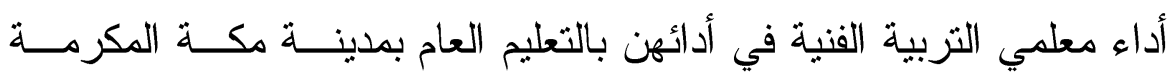
بالمملكة العربية السعودية.

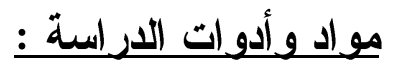
- معايير الجودة لأداء المعلم في التعليم العام في ظل الكفايات. - المعايير العامة للاعتماد في (NCATE) . -معايير الإدارة العامة للتقويم والجودة التربوية بوزارة التربية والتعليم بالمملكة العربية السعودية. - قائمة المعايير المقترحة لجودة أداء معلمي التزبية الفنية في التعليم العام بالمملكة العربية السعودية. 
كطاقة ملاحظة للأداء التدريسي لمعلمات النزبية الفنية في ضوء المعايير المقترحة لجودة أداء معلم التربية الفنية بالتعليم العام بالمملكة العربية

$$
\text { السعودية. }
$$

مصطلحات الدر اسة و إطار ها النظري :

يتتاول هذا الجزء المصطلحات والأدبيات النظرية للار اسة الحالية وهي (التقويم و الأداء و المعايير و الجودة) و إلقاء الضوء على على مفاهيم الجودة، و الجودة

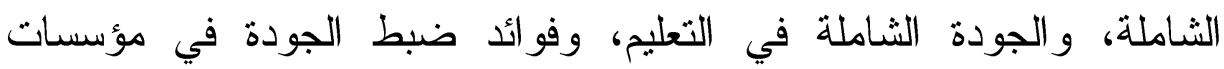

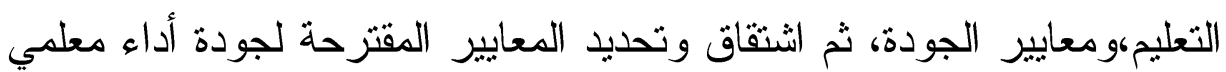
التربية الفنية في التعليم العام بالمملكة العربية السعودية وذللك كما يلي :

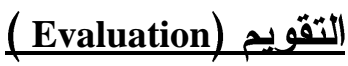

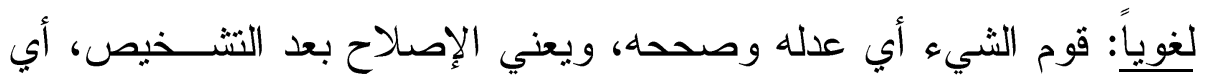

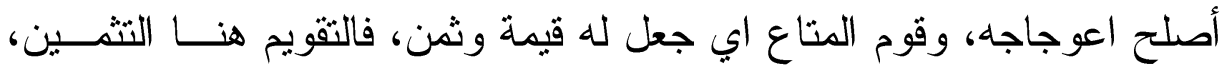

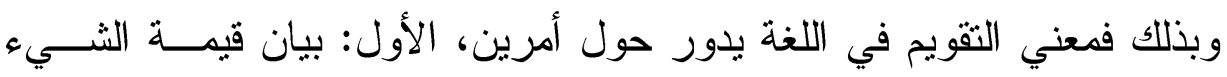

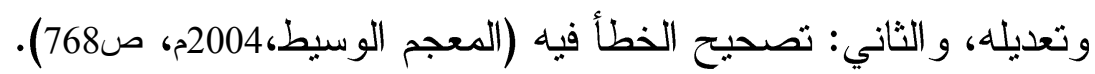

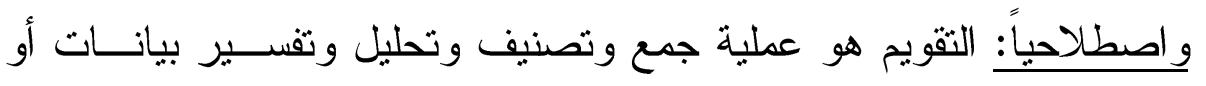

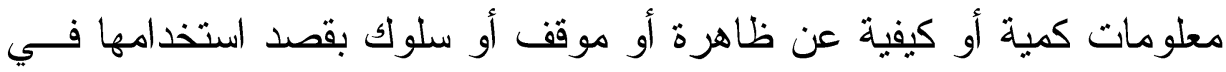

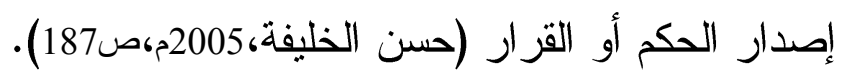

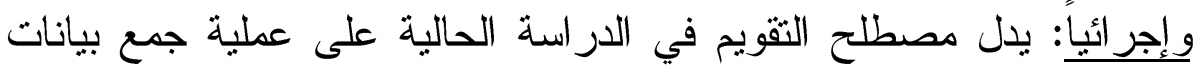

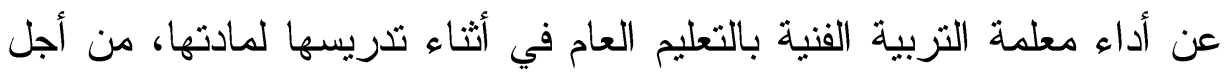

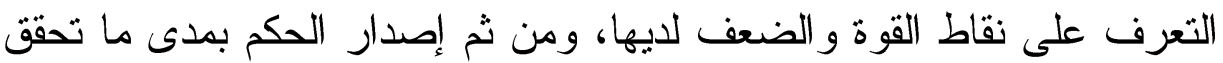
من معايير جودة أداء معلم التزبية الفنية في أدائها.

الأدلاء: Performance 
لغوياً: ورد في لسان العرب(ابن منظور،2003م،صأصنام) أن الأداء هو أداة

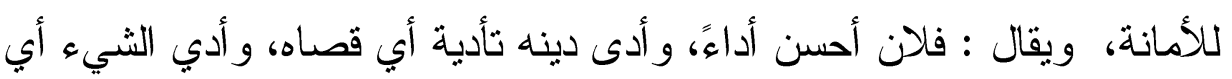
قام باه وقضاه.

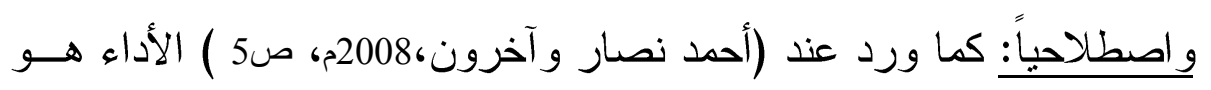

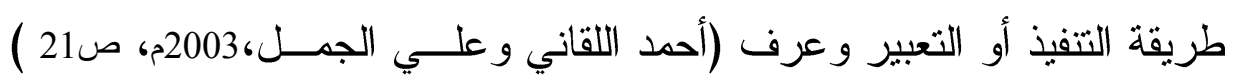

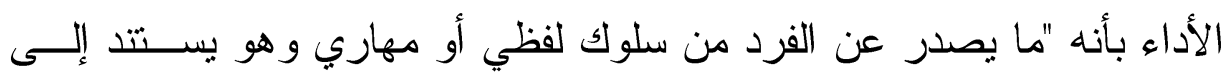

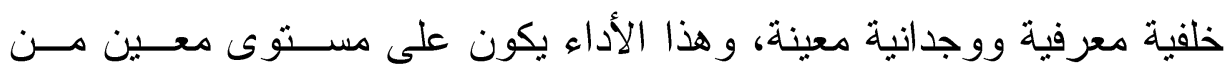

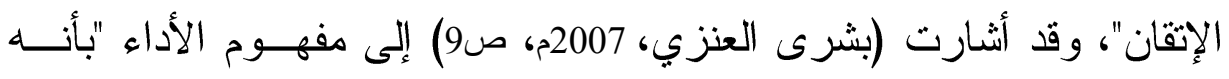

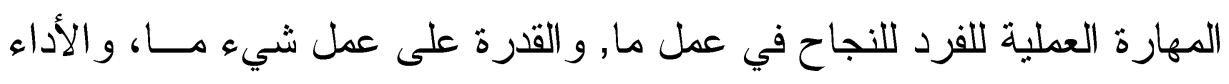

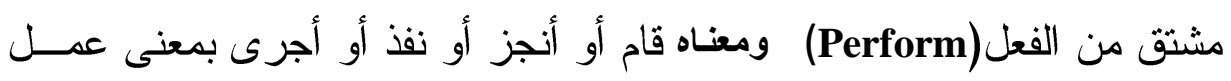

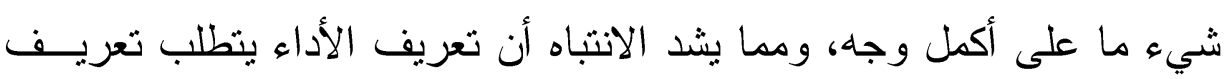

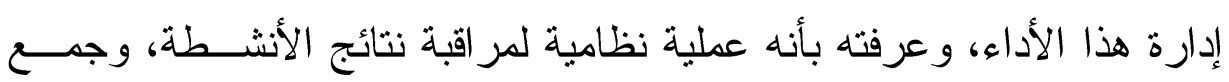

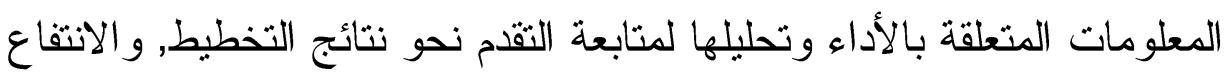

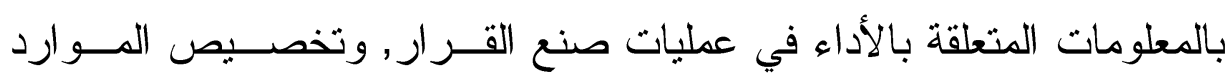

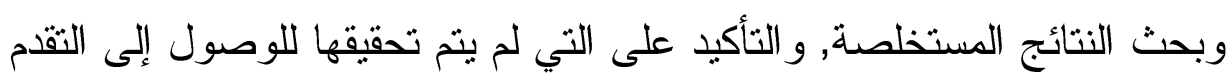
المنشود.

و إجر ائياً: يقصد بالأداء في الدر اسة الحالية كل ما تقوم به معلمــة التربيــة

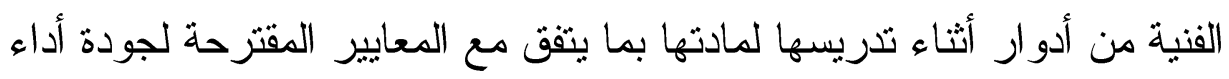
معلم التربية الفنية الني توضحها نتائج بطاقة الملاحظة المستخدمة.

\section{المعايير:Standards}

لغوياً:جاء في المعجم الوسيط "العيار" ما اتخذ أساساً للمقارنة و التقدير،و عيار

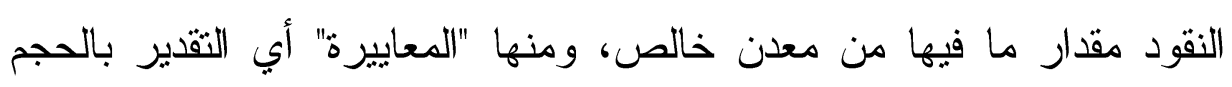
بمحاليل قياسية ومعروفة قوتها و المعيار في الفلسفة نموذج متحقق أو متصور لما يكون عليه الشيء. 


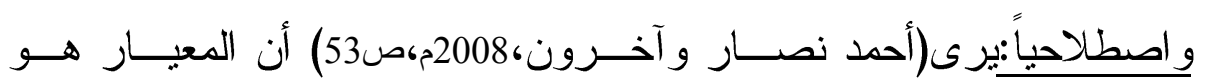

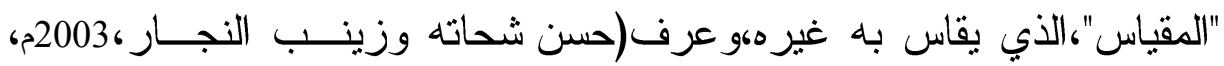

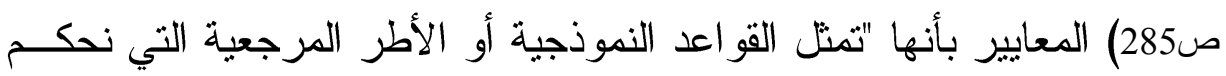

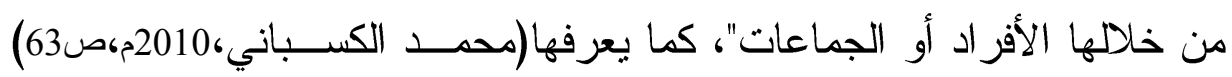

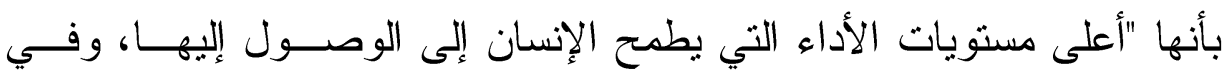
ضوئها يتم تقويم مستويات الأداء المختلفة و الحكم عليها". و إجر ائياً:بقصصد بالمعايير في الدر ماسة الحالية مجموعة من المحددات الأساسية والأداءات الفعالة التي تستخدم للحكم على جودة أداء معلمة التزبية الفنية وذلك فئل أثناء تدريسها لمادتها.

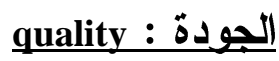

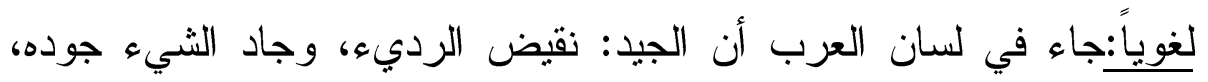

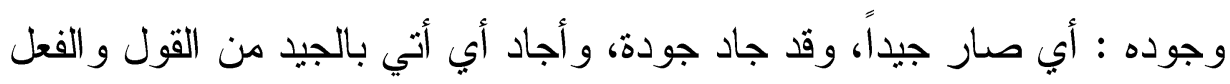

$$
\text { (ابن منظور 1984م، صدوه : (72). }
$$

و اصطلاحياً:عرفتها الجمعية الأمريكية للجودة، بأنها الهيئة و الخصائص

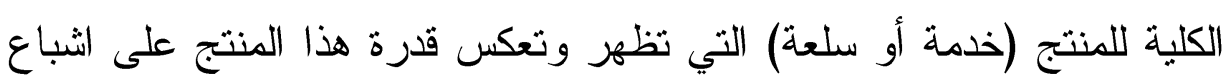

$$
\text { حاجات صريحة و أخري ضمنية. }
$$

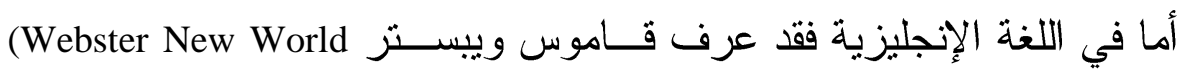
الجودة بانها : "صفة أو درجة تفوق بمتلكها شيء ما كما Dictionary,1998,48)

$$
\text { تعني درجة الامنياز". }
$$

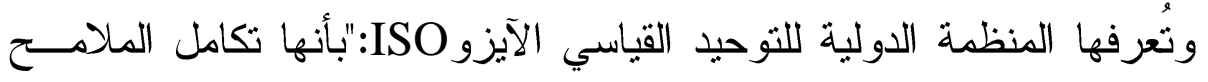

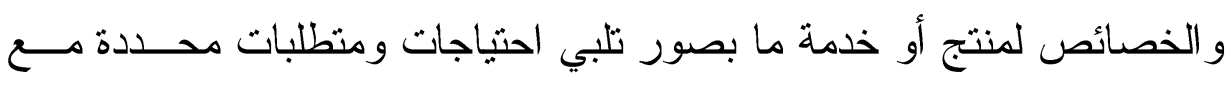

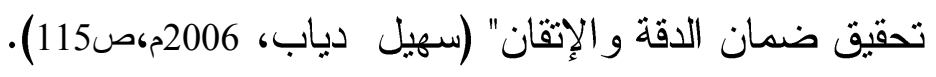

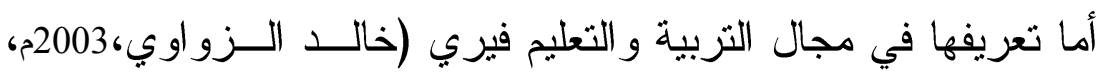
ص34) بأنها:"معايير عالمية للقياس و الاعتر اف والانتقال من ثقافة الحد الأدنى فيري doi : 10.12816/0004231 
إلى ثقافة الإتقان و التمييز، و اعتبار المستقبل هدفاً تسعي إليه، والانتقـال مـن

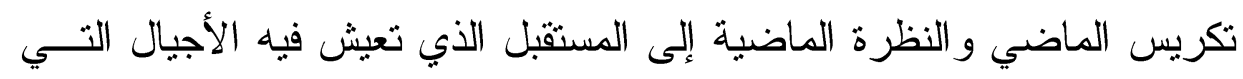

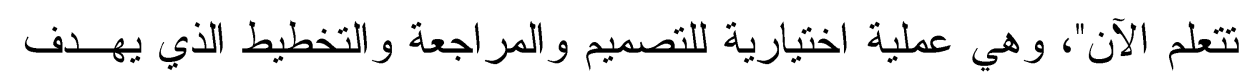

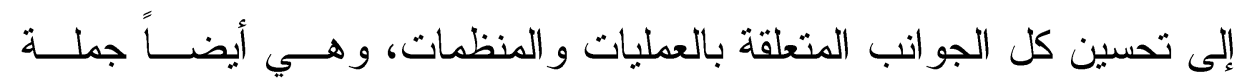

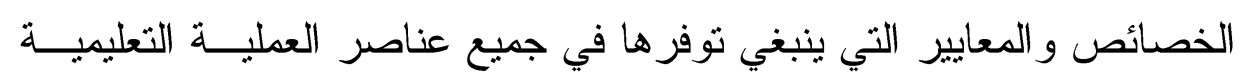

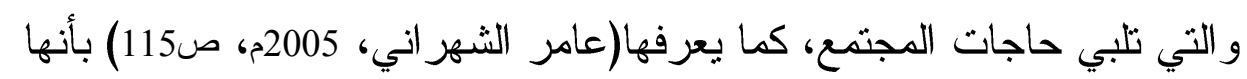
"أداء العمل بطريقة صحيحة وفق مجموعة من المعايير و المواصفات التزبوية لئية اللازمة لرفع مستوى جودة المنتج التعليمي بأقل جهد وتكلفة". و إجرائياً: يقصد بالجودة في الدراسة الحالية هي تطبيق مجموعة من المعايير

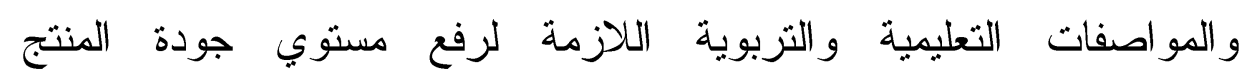
التعليمي(المتعلمات)،و عليه تعرف الباحثة جودة أداء معلمة التربية الفنية بأنها:

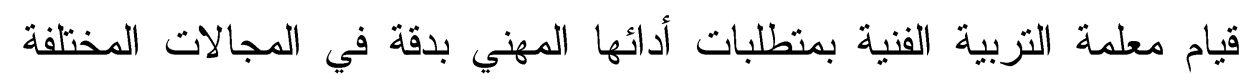

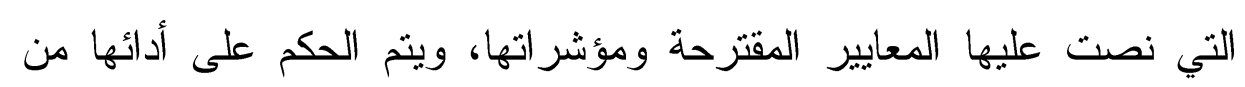
خلال نتائج بطاقة الملاحظة المستخدمة في الدر اسة الحالية. 
The concept of Total quality : الجودة الشاملة تتفق معظم أدبيات الجودة بأن محاولة تعريف معني الجودة الثـــاملة يمكـن تتاوله من جوانب متعددة نظراً لاختلاف التصورات حــول المفهــوم ونــوع

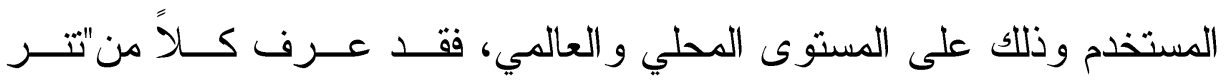
وديتورو"(Tenner\& Detoro,1992,31)الجودة الشاملة بأنها "اســتر اتيجية عمـلـ أساسية تسهم في تقديم سلع وخدمات ثرضي بشكل كبير العملاء فــي الــداخل و الخارج، وذلك من خلال تلبيــة توقعــاتهم الضــمنية و الصــريحة، وهــذه الاستر اتيجية تستخدم مهار ات العاملين وقدر اتهم الذاتية لصالح المنشأة بشــكل خاص و المجتمع بشكل عام، كما انها تسهم في دعم الوضع المالي للمساهمين،

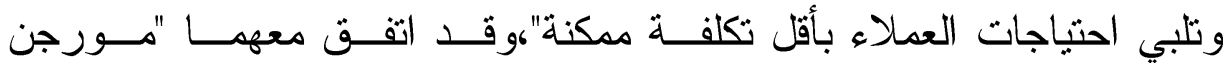
ومورجاترويد" (Morgan\& Murgatroyed,1994,90) اللذان عرفا الجودة الثـــاملة بأنها "عملية تلبية احتياجات العميل ومتطلباته المشروعة بالقدر المطلوب". و الو اقع أن محاو لات تعريف الجودة الثاملة لا تزال مستمرة نظر التطــور

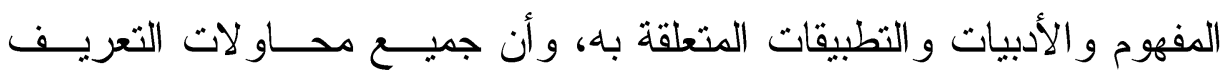
تضمنت دلالة و احدة لتعريف الجودة الثاملة وهي مقابلة الاحتياجات و التطلعات الحالية و المستقبلية للمستقيدين من المنتج أو الخدمة، وهي فلسفة مبنيــة علــى رضا المستقيد لضمان اتقان المنتجات المقدمة، و الحصول على أكبر قدر مـن الرضنا مقابل أقل قدر من الاستهلاك لمدخلات عملية الانتاج وهي الغاية التـي تتطلع إليها كل مؤسسة أو منشاة، ومهما كانت التعريفات التي تعرضت إلـى مفهوم الجودة الشاملة الا أنها ثشترك في العديد من المسلمات أهمها : •التركيز على تحسين المنتج الذي بُعد المخرج النهائي لأي نظام. •إدارة الجودة تُعد فلسفة و استر اتيجية طويلة الأمد، وتحتــاج إلــى أســاليب ابتكاريه وتوليد أفكار . 
•تحتاج إدارة الجودة الثاملة إلى مجهود كبير ومدة للحكم على مدى نجاحها في تحقيق الأهداف. الجودة الشاملة في التعليم: تصني الاهدي

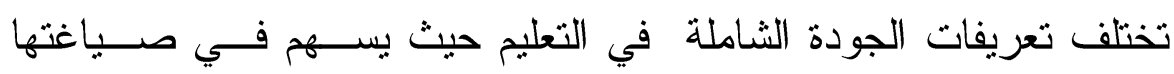

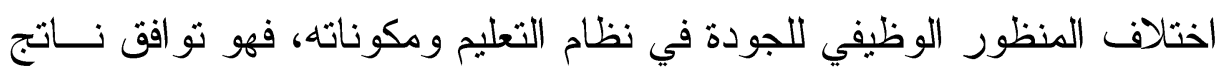

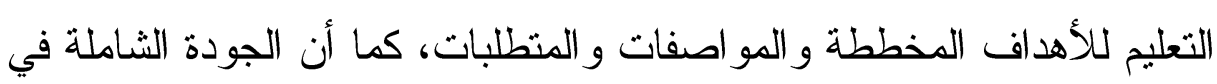

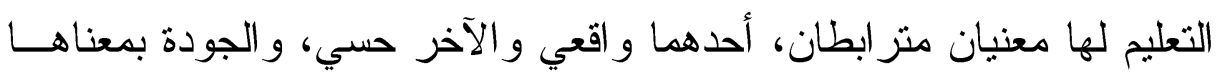

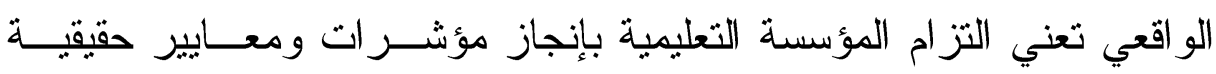

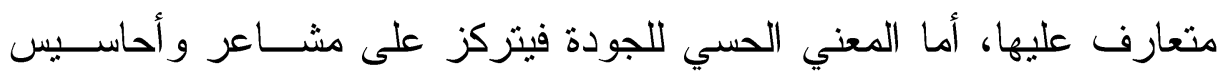

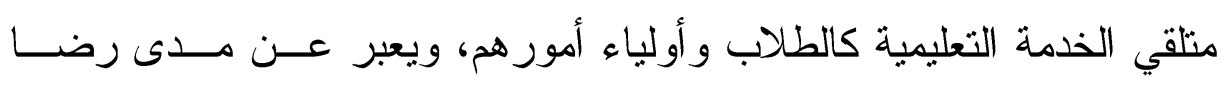

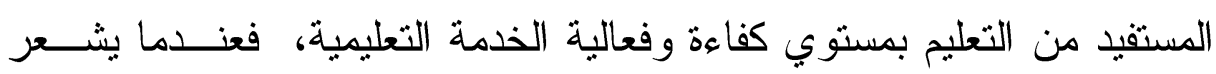

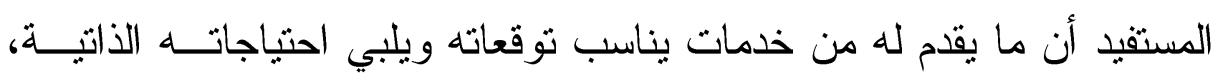

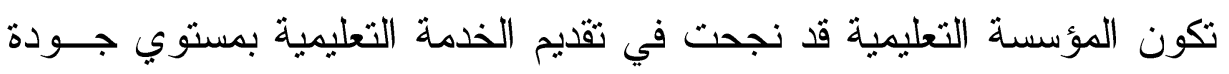
يناسب النوقعات و المشاعر الحسية للمستقيد، وأن جودة خدماتها قد ارتفعت إلى نى

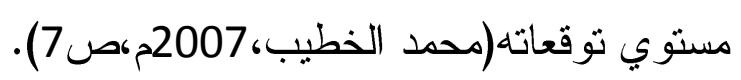

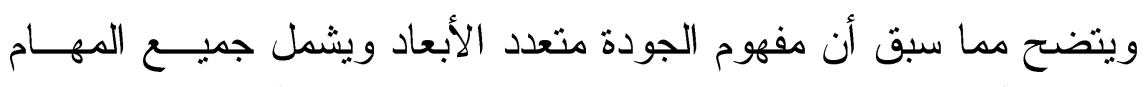

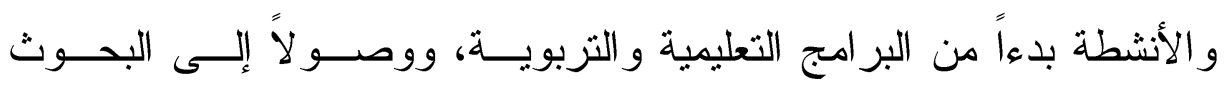

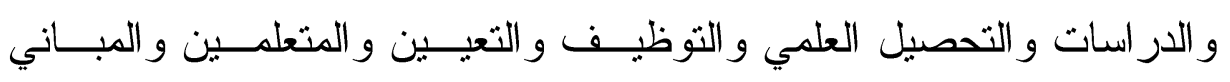

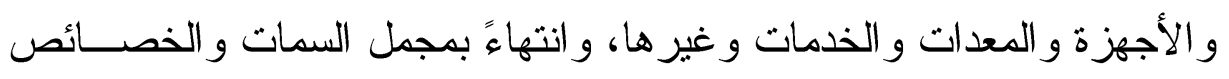

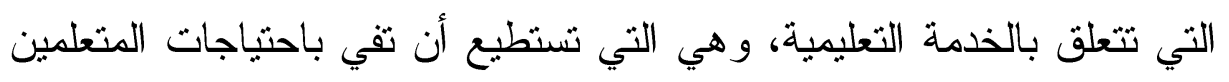
وتحقق أهداف وغايات سياسة التعليم العام.

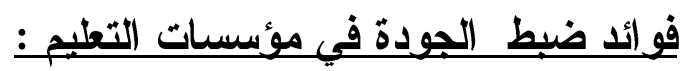
- وضوح البر امج الأكاديمية ومحتوياتها. 
- توفير معلومات و اضحة ودقيقة للطلاب و غير هم من المعنيين حــول أهـــداف

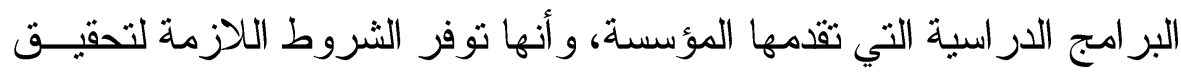
هذه الأهداف بفاعلية.

-التأكد من أن الأنشطة التزبوية للبر امج المعتمدة تتثقن مع المعــايير العالميــة

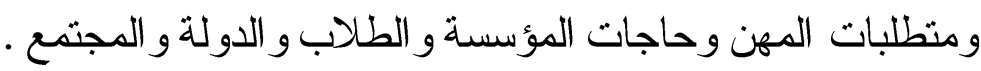

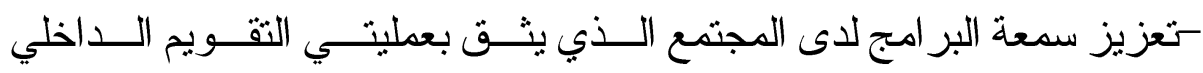

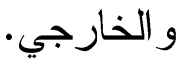
-توفير آلية لمساعلة جميع المعنيين بالإعداد و التنفيذ و الإثر اف على البــر امج الأكاديمية.

-تعزيز ودعم ثقة الدولة والمجتمع بالبر امج الأكاديمية التي تقدمها المؤسسة .

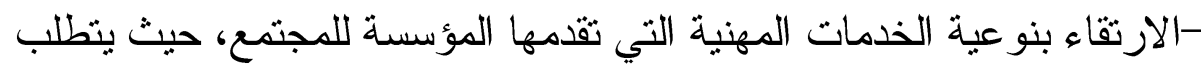

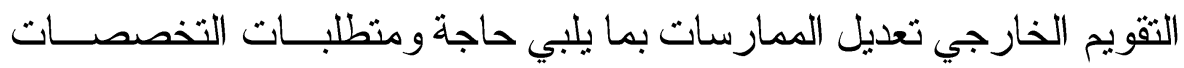

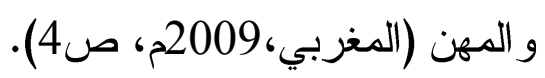

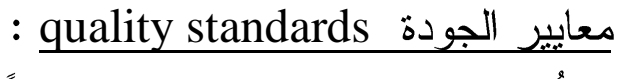

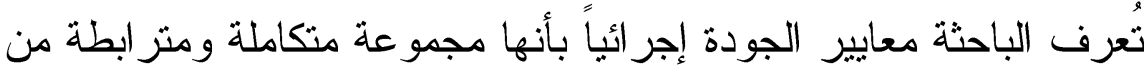
المحكات و المؤشر ات موزعة على عدد من مجالات الجودة المتعلقـــة بنظـــام

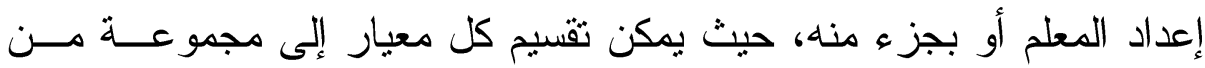

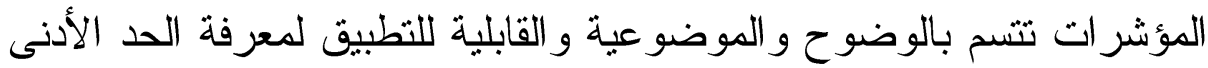

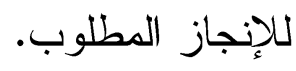

ولنطبيق الجودة في مجال التعليم العام لابد من اتخاذها قيمه محورية، بحيث

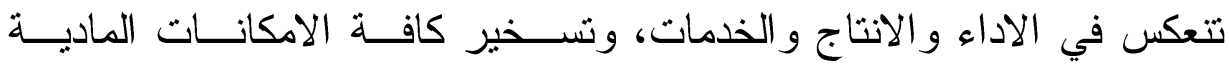

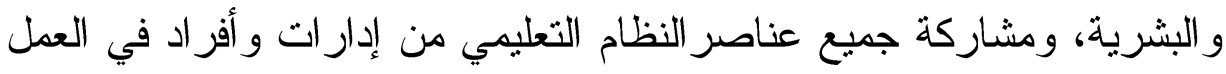

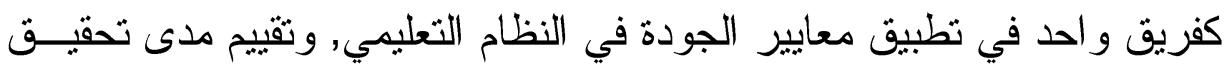

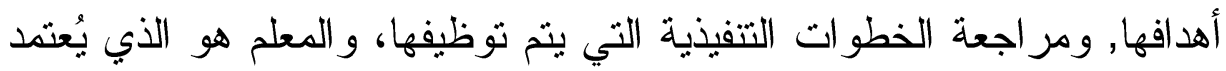


عليه بشكل أساسي في تطبيق نظام الجودة في التعليم للحصول على مخرجات

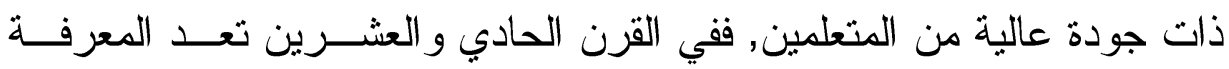

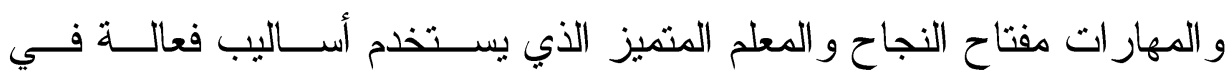

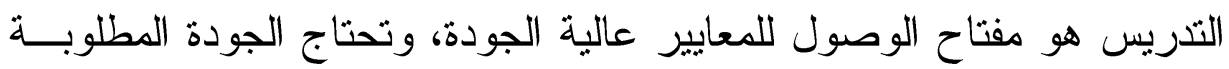

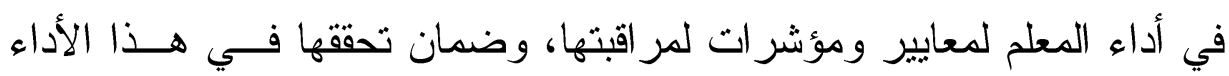

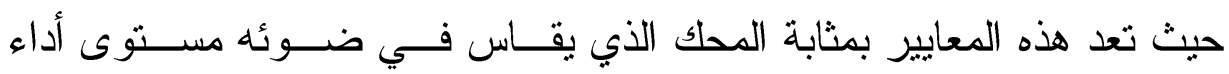

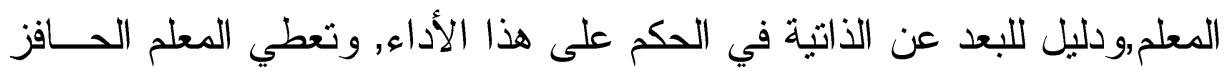

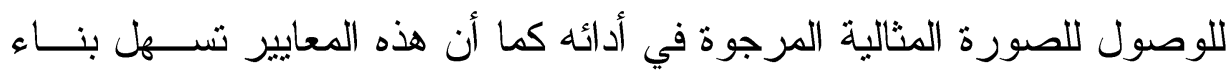

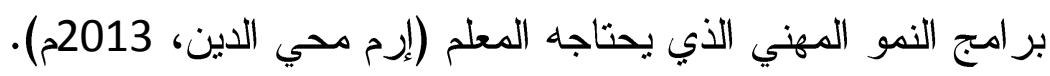

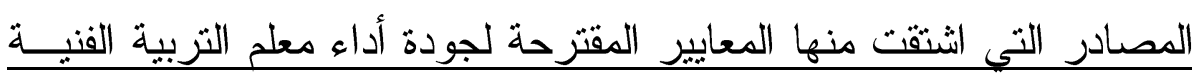
في التعليم العام: لقد ثم اشثقاق واستخلاص المعايير المقترحة لجودة أداء معلم التزبية الفنية

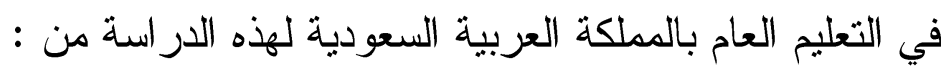

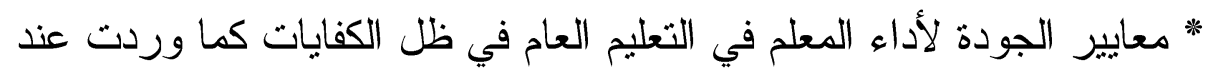

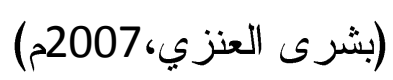
لكي يقوم المعلم بجو انب أدواره السابقة بكل كفاءة و اقتدار في ضو هو معسايير

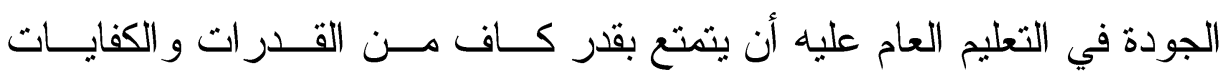

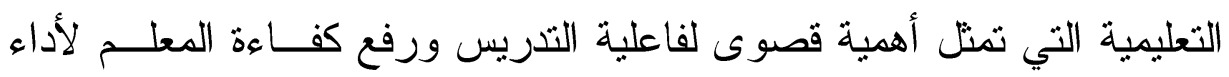

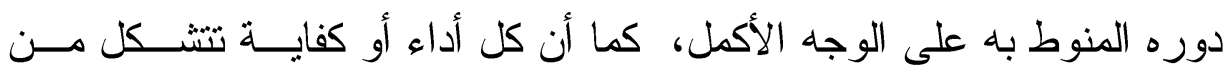
مكونين رئيسين هما: المكون المعرفي والمكون السلوكي، فالمكون المعرفيـي

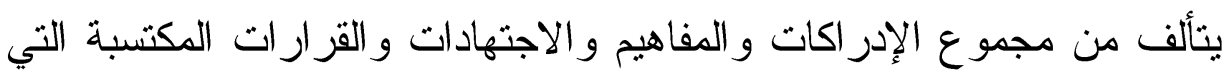

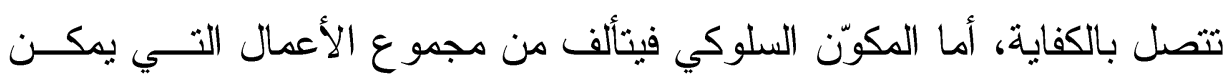

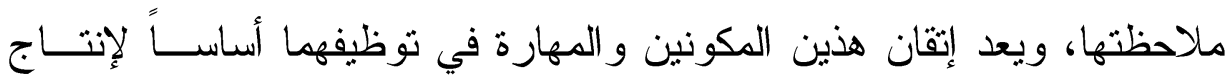
المعلم الكفء الفعال. 
وثزى الباحثة ضرورة ربط المعايير بالكفايات بأدوار المعلــم، لأن تحديــــ

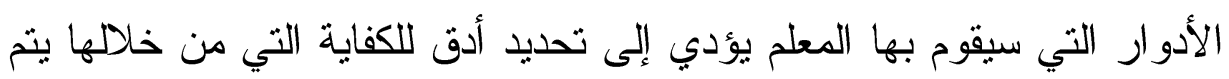
تحديد قائمة المعايير المقترحة.

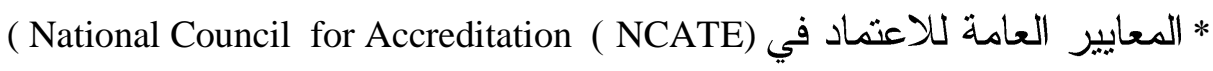
.of Teach Educatio)

و (انكيت NCATE)هي مؤسسة من مؤسسات الجودة و الاعتماد الأكـاديمي

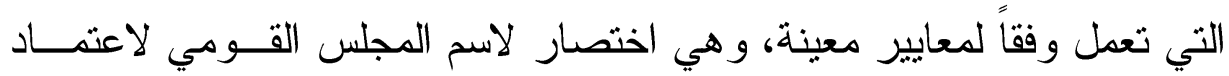
إعداد المعلمين وهو مجلس أمريكي يمنح مؤسسات برامج إعداد المعلم اعتماداً

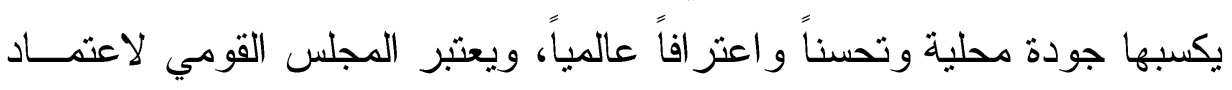

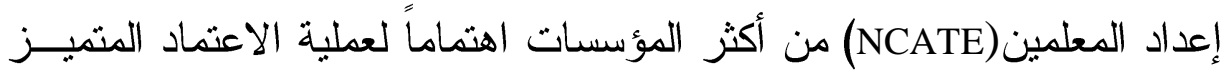

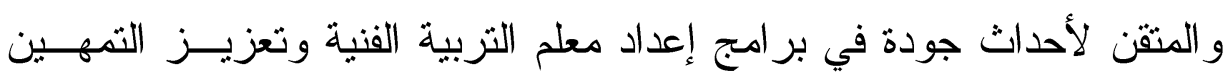

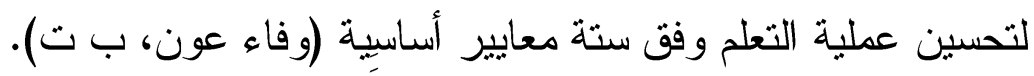

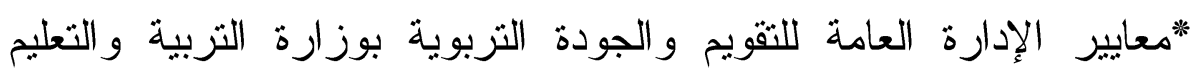

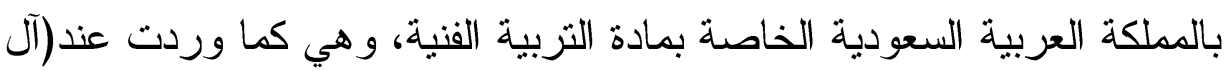
زاير و آخرون، 2011م). قائمة جدولية توضح المجال و المعيار و المؤشرات للمعايير المقترحة لجودة أداء معلمي التتربية الفنية في التعليم العام بالمملكة العربية السعودية :

\begin{tabular}{|c|c|c|}
\hline المؤشر ات & المعيار & المجال \\
\hline 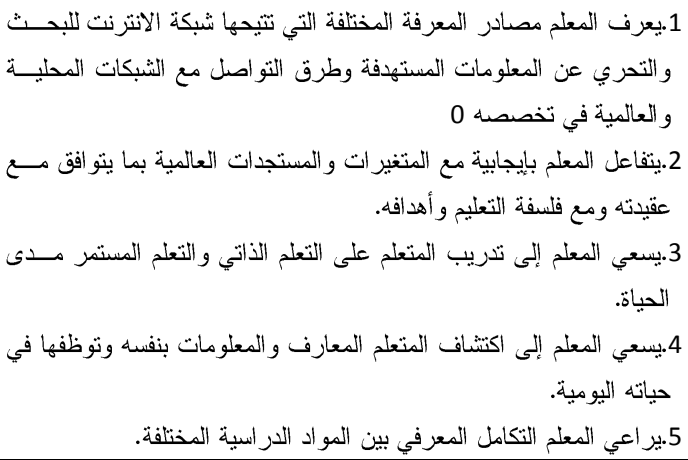 & 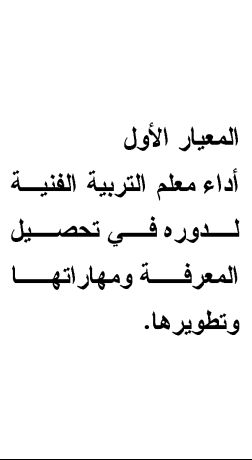 & المعرفة \\
\hline 7 6يصني المعلم باهتمام إلى المتعلم و آرائه ومقترحاته وتتجيعه على طــرح & 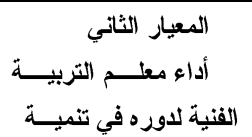 & \\
\hline
\end{tabular}




\begin{tabular}{|c|c|c|}
\hline 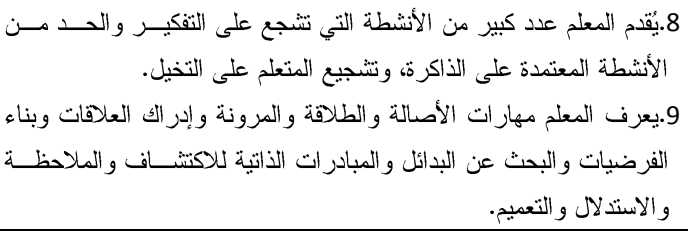 & أنواع التفكير ومهاراته. & \\
\hline 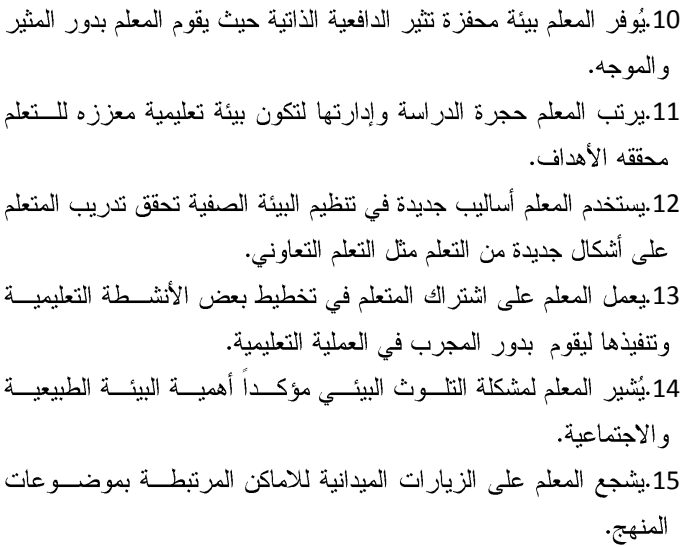 & 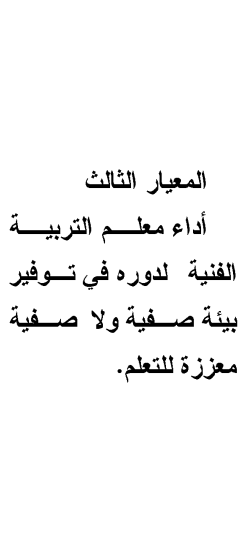 & مجال البيئة \\
\hline 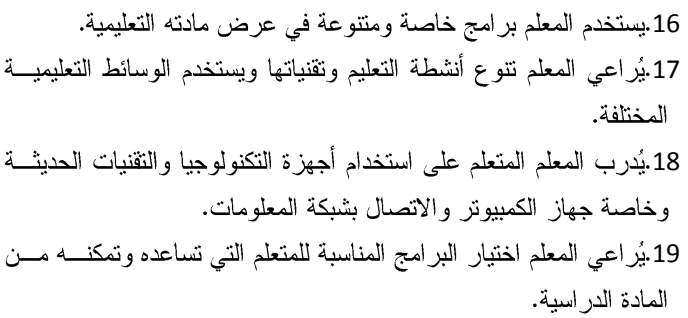 & 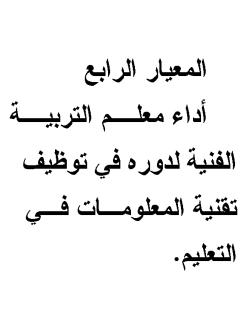 & المجلومات تقنية \\
\hline 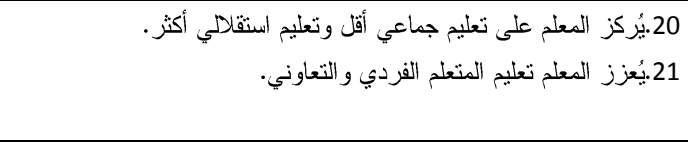 & ألداء معلم التربية الفنيـــة & مجال تفريد \\
\hline 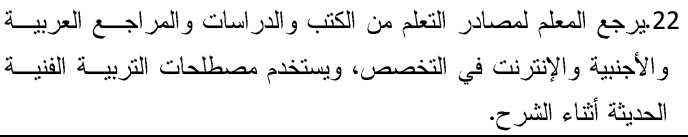 & 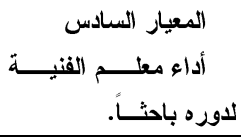 & مجال البحث \\
\hline 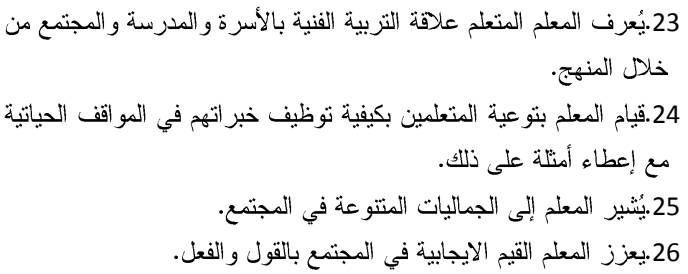 & 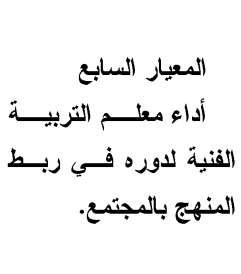 & المجتمع \\
\hline
\end{tabular}


معايير مقترحة لتقويم أداء معلمات الثربية الفنية بالتعليم العام د.أميرة عبد الرحمن منير الدين

\begin{tabular}{|c|c|c|}
\hline 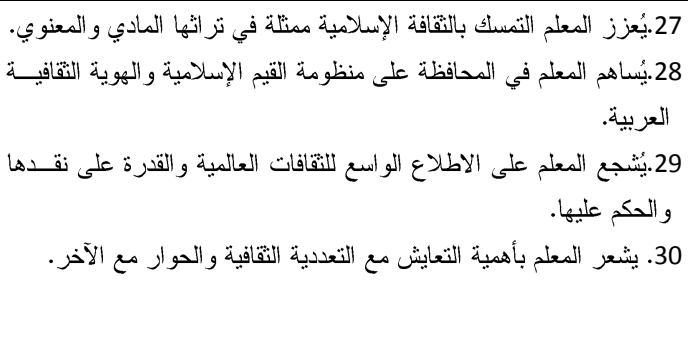 & 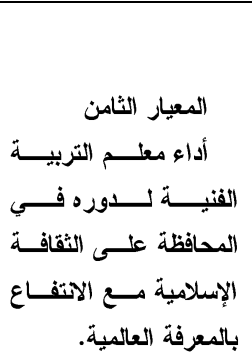 & والإلثقافة \\
\hline 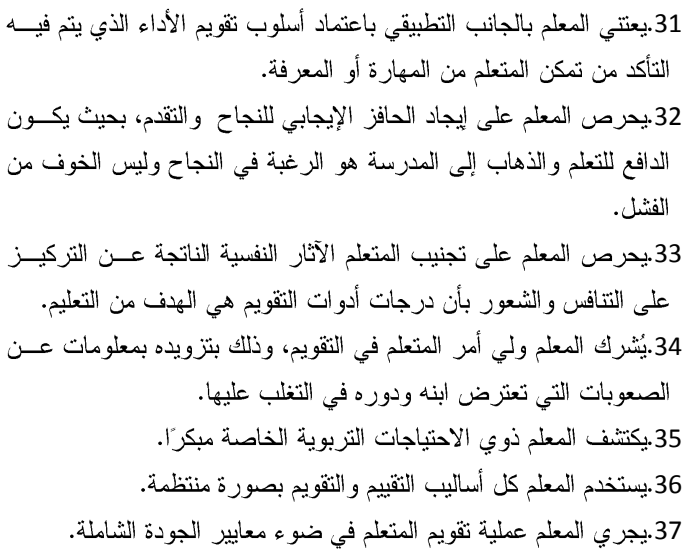 & 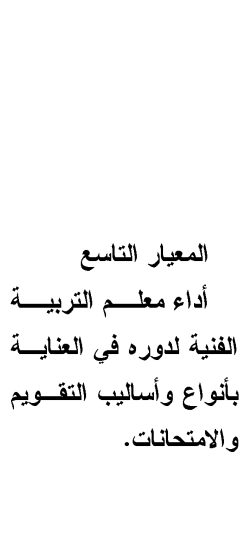 & والامتويم \\
\hline 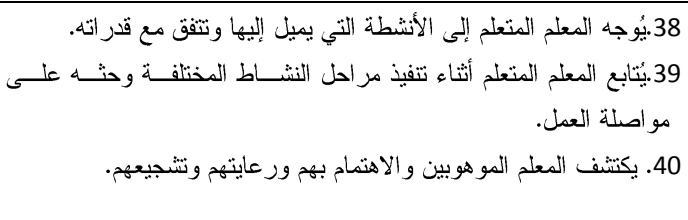 & 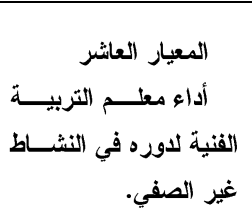 & النشاط غير \\
\hline 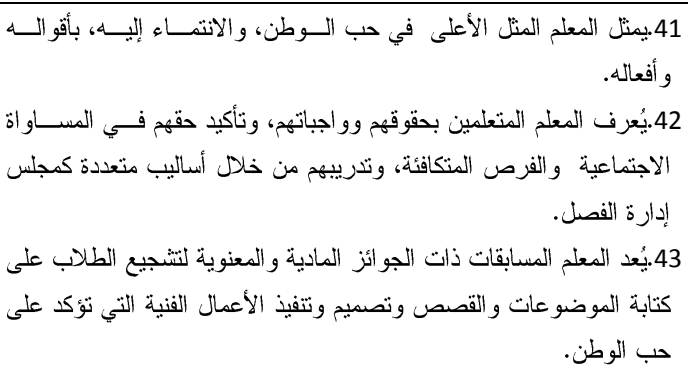 & 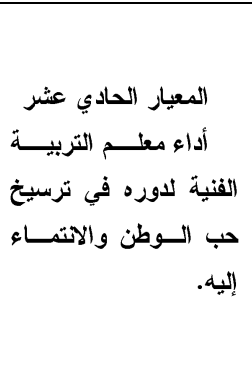 & 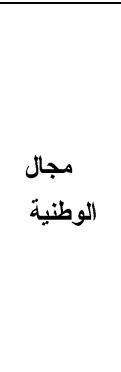 \\
\hline 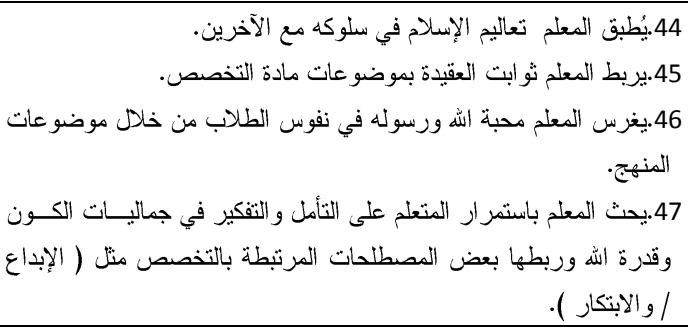 & 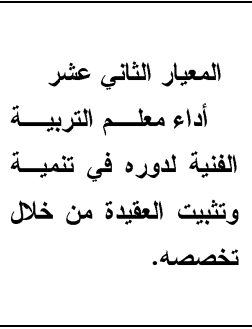 & 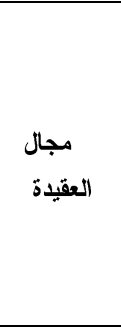 \\
\hline 48.بيادر المعلم بالتسامح و السلام. & ألداء معلم التربية الثالث عثر الفنية & 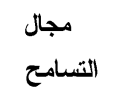 \\
\hline
\end{tabular}

doi : 10.12816/0004231 


\begin{tabular}{|c|c|c|}
\hline 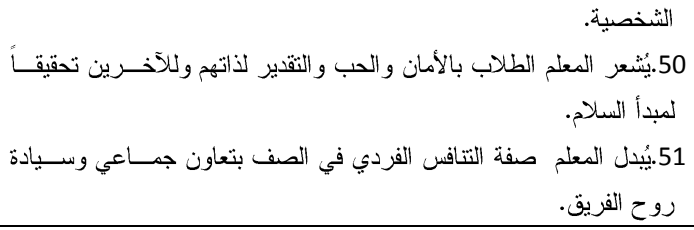 & لاورده في الــــعوة إلــى & و السلام \\
\hline 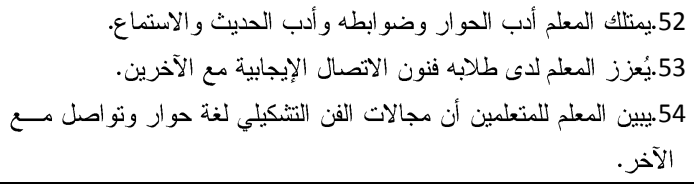 & 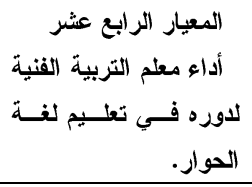 & الحوار \\
\hline 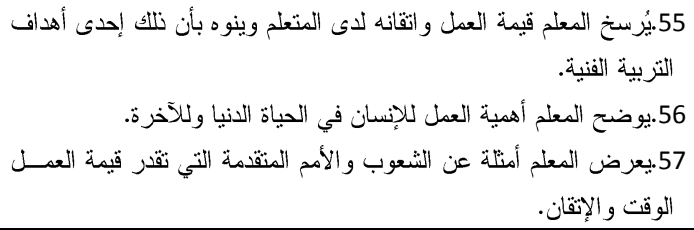 & 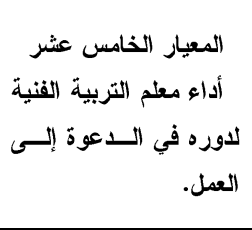 & العمل \\
\hline 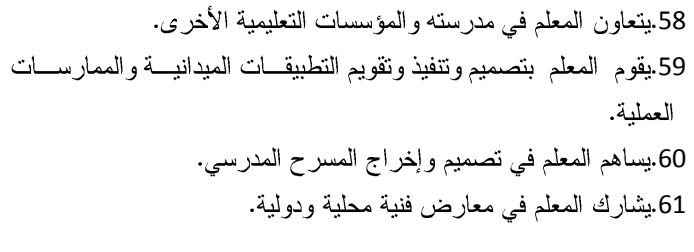 & 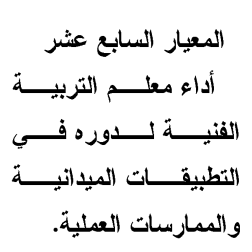 & و المبارل \\
\hline 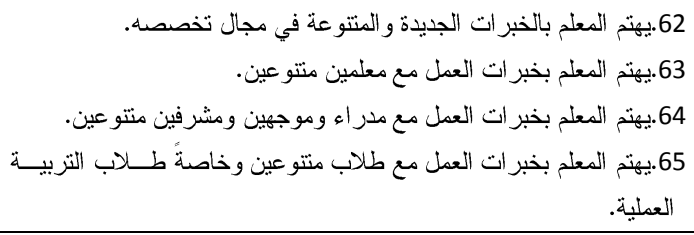 & 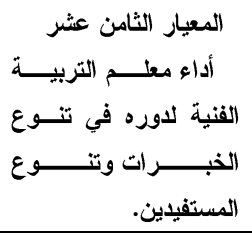 & التنوع مجال \\
\hline 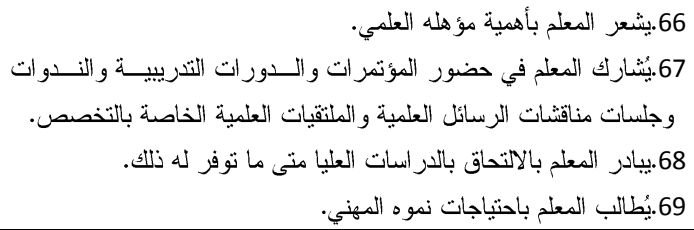 & 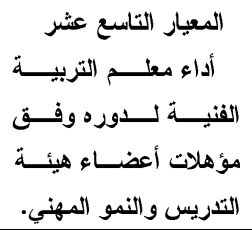 & المجنو \\
\hline 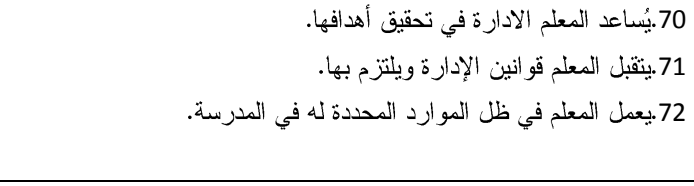 & 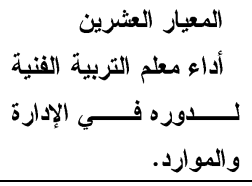 & و الإدارة \\
\hline 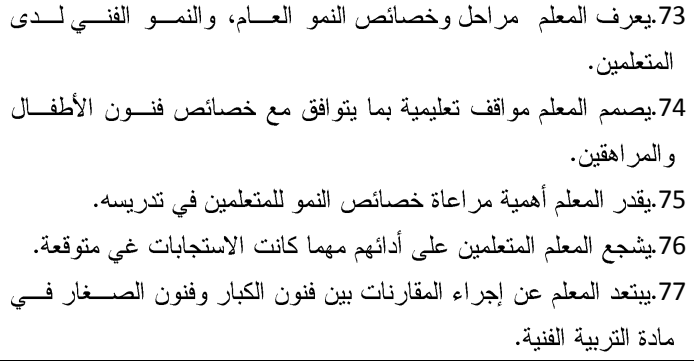 & 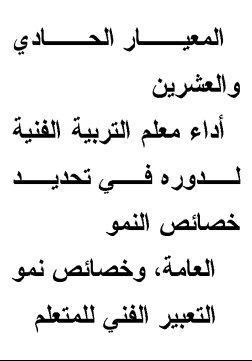 & وخصائصة \\
\hline
\end{tabular}


معايير مقترحة لتقويم أداء معلمات التربية الفنية بالتعليم العام د.أميرة عبد الرحمن منير اللين

\begin{tabular}{|c|c|c|}
\hline 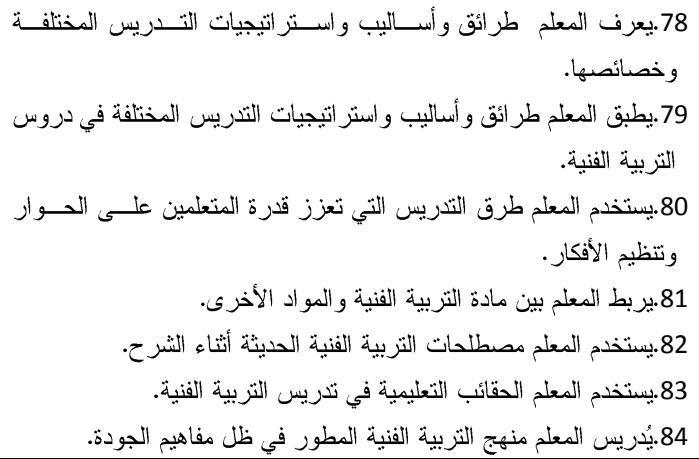 & 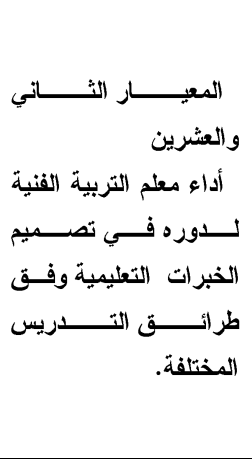 & طرث \\
\hline 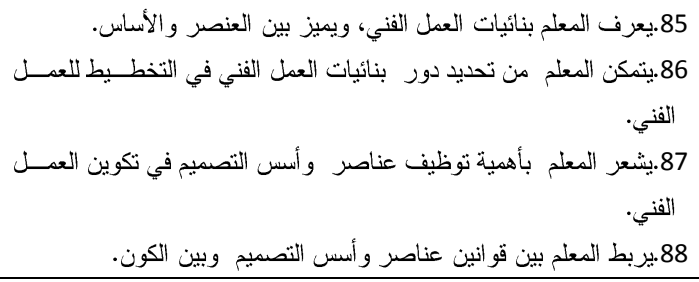 & 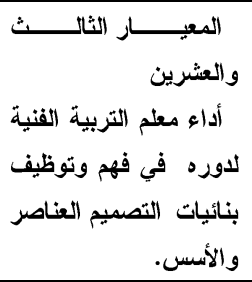 & إنتاج الفنات \\
\hline 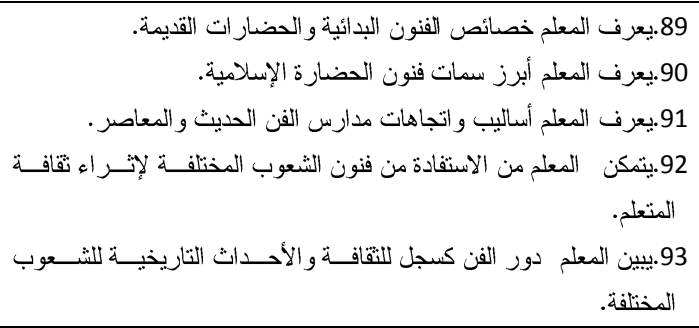 & 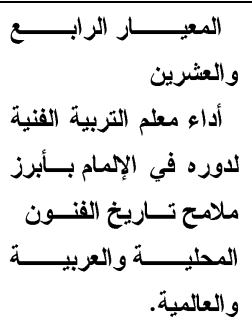 & تاريخ الفن \\
\hline 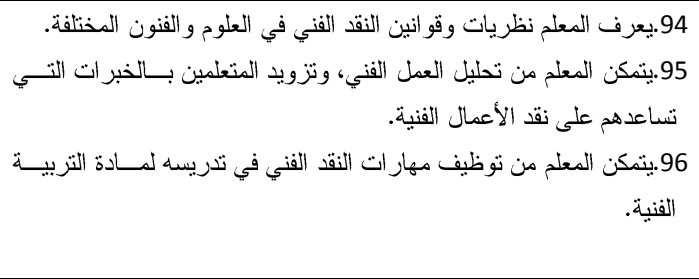 & 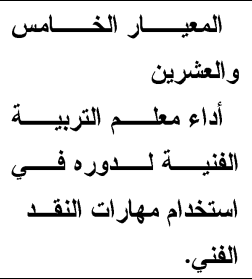 & النقا الفني \\
\hline 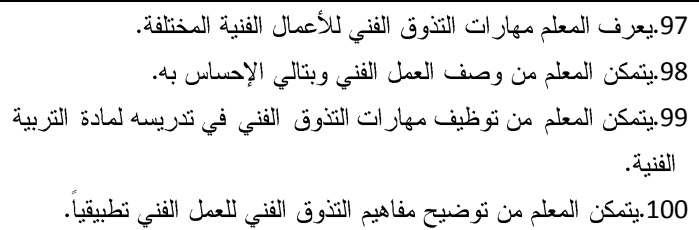 & 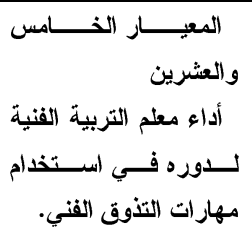 & التذبق \\
\hline 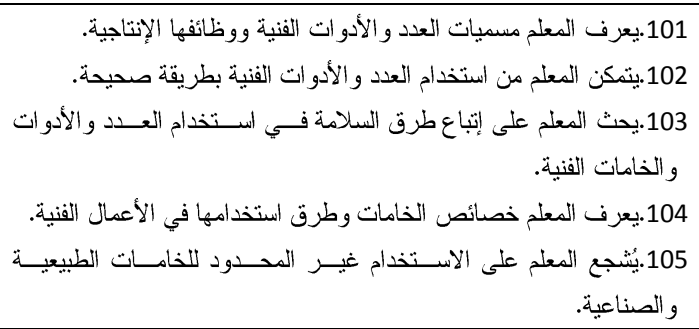 & 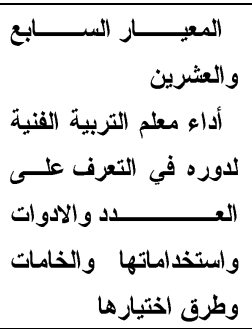 & والخامات \\
\hline 106.يعرف المعلم استخدامات الحاسب الآلى. & المعيــــــار الثــــــامن & مجال \\
\hline
\end{tabular}

doi : 10.12816/0004231 
مجلة الاراسات التربوية والاسانية ـ كلية التربية ـ جامعة دمنهور ـ المجلد السادس - العدد الاول - لسنة 2014

\begin{tabular}{|c|c|c|}
\hline 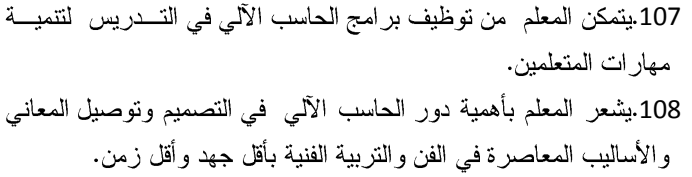 & توأل ألعشرين معلم التربية الفنبة & الفقإتيات \\
\hline 109 109.يعرف المعلم العلافة بين الخيال و الإبداع وتتمية التفكير الابتكاري. & 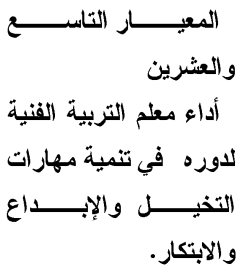 & و الالإلباع \\
\hline 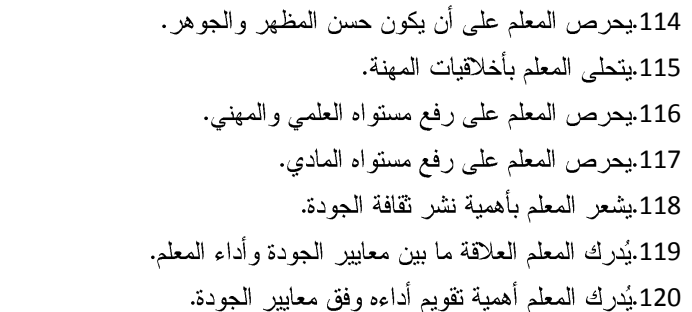 & 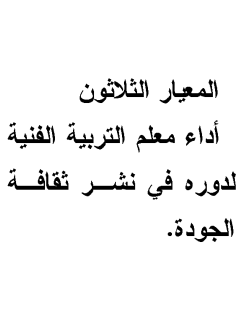 & الثخات \\
\hline
\end{tabular}

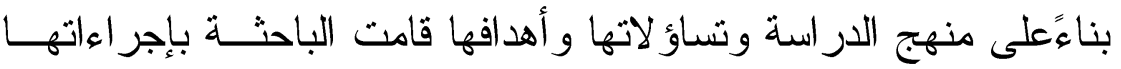
الميدانية لنقديم الاجابة على التساؤلات و الوصول إلى نتائج الدراسة وذللك كما :بلي : * نص السؤال الأول: ما الجودة ؟ وما الجودة الثاملة ؟ وما الجودة الثــاملة

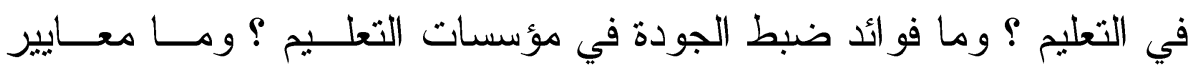

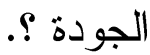

* نص السؤال الثاني: ما المصادر التي اثشتت منها المعايير المقترحة لجودة

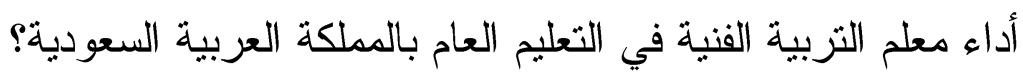
*نص السؤال الثالث:ما المعايير المقترحة لجودة أداء معلمي التربية الفنية في التعليم العام بالمملكة العربية السعودية؟ * نص السؤال الرابع: ما مستوى ثو افر معايير الجودة المقترحسـة فــي أداء معلمات التزبية الفنية في التعليم العام بالمملكة العربية السعودية ؟ 
للإجابة عن السؤال الأول والثاني والثالث من أسئلة الدراسة اتبعت الباحثة

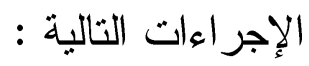

-الاطلاع على الكتب و المر اجع و الدر اسات السابقة للتعرف على الأدبيات التي تتاولت منطلبات عصر الجودة الثاملة وتحدياته في مجال التعليم، ومنها تم تحني عرض وتقديم المفاهيم والأطر النظرية الخاصة بالدر اسة الحالية. -الاطلاع على منهج التربية الفنية المطور في مرحلة التعليم العام (الابتدائي و الإعدادي و الثانوي). -مقابلة بعض المتخصصات من معلمات وموجهات التربية الفنية للتعرف على والى

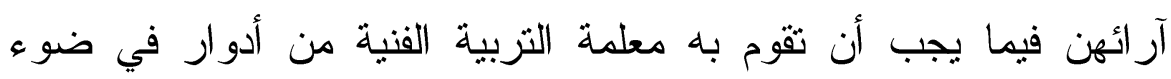
معايير الجودة. -الاطلاع على معايير الجودة لأداء المعلم في التعليم العام بصفة عامة، ومعايير الاعتماد في ( NCATE) ومعايير الإدارة العامة للتقويم والجودة التزبوية بوزارة التربية و التعليم بالمملكة العربية السعودية للتربية الفنية.

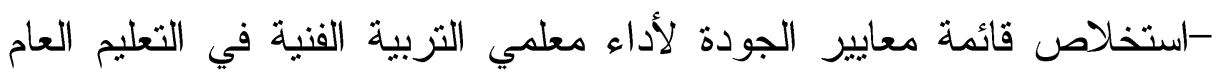
بالمملكة العربية السعودية. - إعداد قائمة مجدولة تحدد المجال والمعيار والمؤشرات لمعايير الجودة المقترحة لأداء معلمي التزبية الفنية في التعليم العام بالمملكة العربية السعودية. وللتوصل إلى هذه القائمة المجدولة تم إتباع الخطوات التالية:

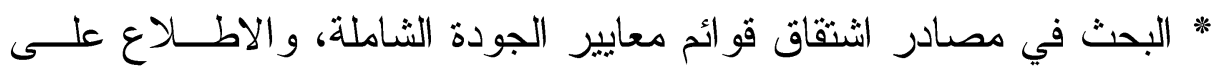

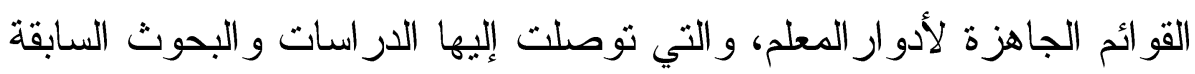

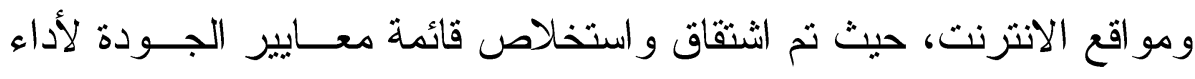
معلمي التربية الفنية في التعليم العام بالمملكة العربية السعودية. 
* ضبط قائمة المعايير المقترحة لجودة أداء معلمي التربية الفنية في التعليم العام بالمملكة العربية السعودية.

بعد إعداد قائمة المعايير المقترحة في صورنها المبدئية تم عرضها على بلى

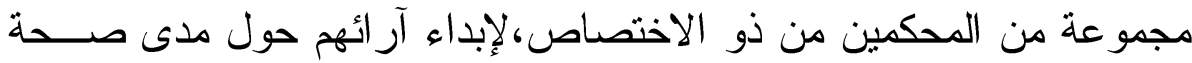

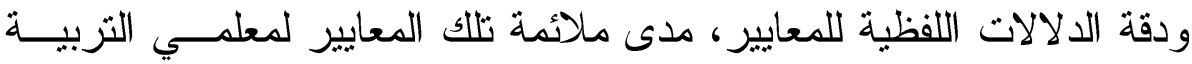
الفنية بالتعليم العام، ومدى شمولية هذه المعايير ،وتم اجر اء التعديلات اللازمة مدهة في ضو ء آر اء ومقترحات المحكمين، وبذلك تحقق صدق القائمة، و أصبحت قائمة المعايير المقترحة في صورتها النهائية، وبذلك يكون قد تمت الإجابة

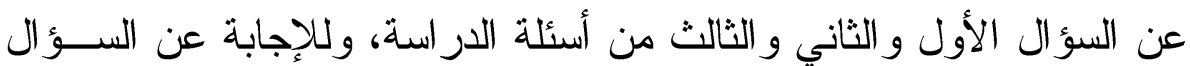

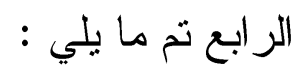

أو لاً: إعداد بطاقة ملاحظة أداء معلمات التربية الفنية بالتعليم العام في ضوع

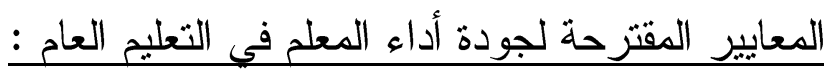
وقد تم إعداد بطاقة الملاحظة وفقاً للخطوات التالية : * تحديد الهدف من بطاقة الملاحظة: هدفت بطاقة الملاحظة إلى تحديد مسدى

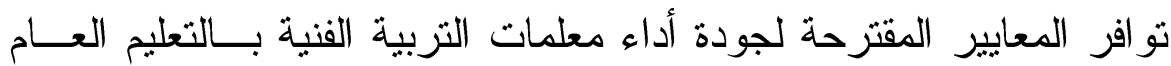
بمدينة مكة المكرمة كعينة تمنل معلمات التربية الفنية بالمملكــة العربيـــة السعودية،وذلك من خلال ممارستهن الفعلية لتدريس التربية الفنبة في حجرة لئه الدر اسة. * تحديد أبعاد بطاقة الملاحظة: احتوت بطاقة الملاحظـــة علـــ(30) مجـــال

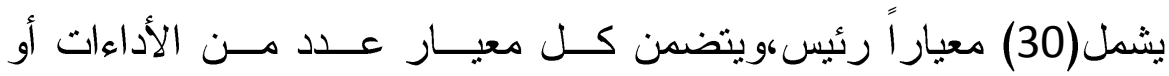
المؤشرات التي تقيسه، حيث بلغ عدد هذه الأداءات أو المؤشـرات (120) أداءاً أو مؤشر اً. * شكل بطاقة الملاحظة: يحتوي الجزء الأعلى من بطاقة الملاحظـــة علــى

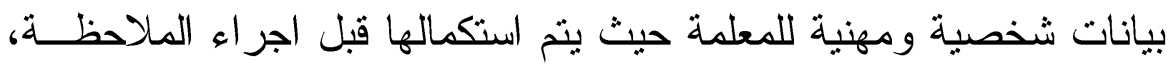


ثم نم وضع الأداءات أو المؤشرات أو بصورة منتالية مع الاحتفاظ بترنيبها

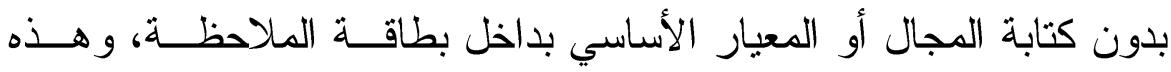

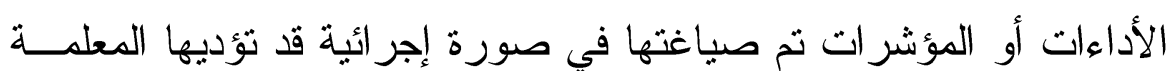
أثناء التدريس بدرجة (مرتفعة - منوسطة -ضعيفة -لم تقم بالأداء).

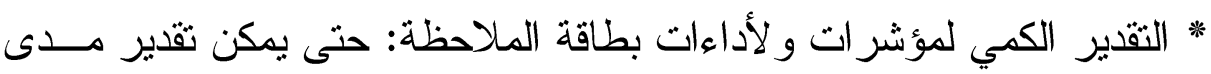

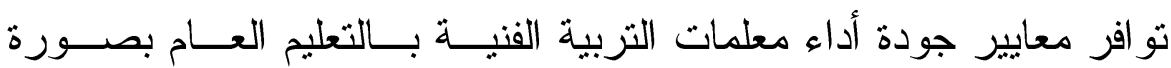

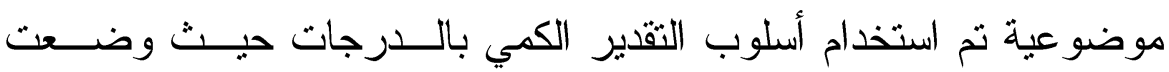

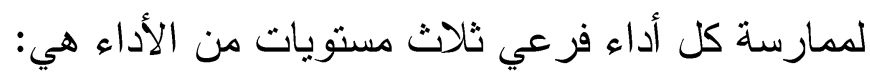

\begin{tabular}{|c|c|c|c|c|}
\hline لم تقم بالأداء & ضعيف & متوسط & مرتفع & الأداء \\
\hline صفر & 1 & 2 & 3 & الدرجة \\
\hline
\end{tabular}

* ضبط بطاقة الملاحظة : يقصد بضبط بطاقة الملاحظة التأكد مـن صــدقها

وثباتها وموضو عيتها، ولتحقيق ذلك اتبعت الباحثة ما يلي : * حساب صدق بطاقة الملاحظة : للتأكد من صدق هذه البطاقة اتبعت الباحثة المرحلتين التاليتين : التين المرحلة الأولي:تضمنت المو اصفات الأساســـية لصـــياغة مفــردات بطاقــة

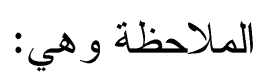

-أن تكون العبار ات سلوكية بمكن ملاحظتها وقياسها. -أن تكون العبار ات و اضحة ودقيقة وموجزة.

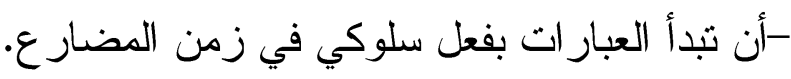
-أن تقيس كل عبارة سلوكاً محدداً و اضحاً. -أن نزتبط الأداءات الفرعية بالمعايير الرئيسة المطلوب ملاحظتها.

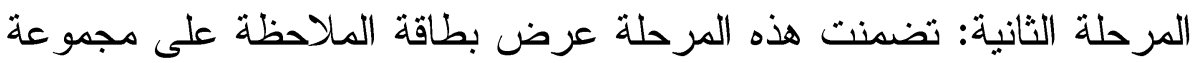

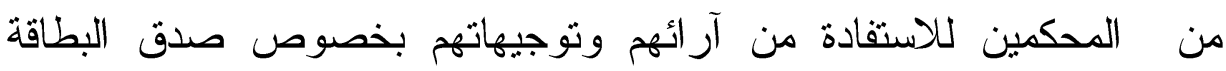
وسلامتها، وقد كانت آراء المحكمين تشير تقريباً إلى صدق البطاقة وسلامتها، 
وقدموا بعض الملاحظات التي تم مراعاتها في الصورة النهائية لبطاقة الملاحظة.

* حساب ثبات بطاقة الملاحظة: لتحديد ثبات بطاقة الملاحظة تم تطبيقها على ماتى عينة استطلاعية مكونة من(10) معلمات من معلمات التربية الفنية بمكة

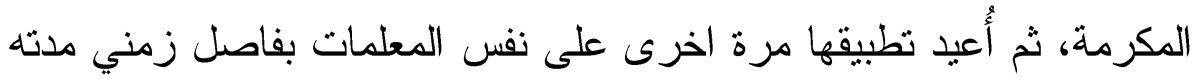

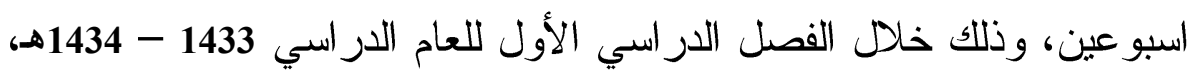
وتم حساب نسبة الاتفاق بين المرتين عن طريق استخدام معادلة "كوبر"

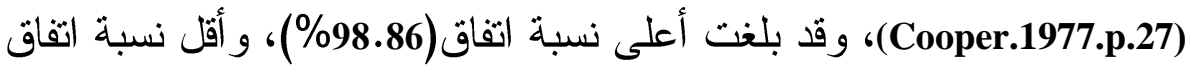

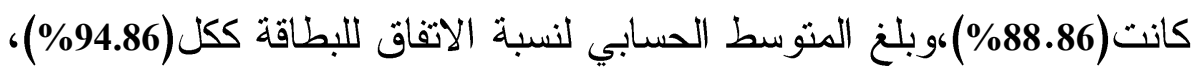
و هو يعد معامل ثبات مرتفع مما يمكن الاطمئنان على مدى ثبات بطاقة الملاحظة.

* حساب موضو عية بطاقة الملاحظة: يتم حساب موضوعية بطاقة الملاحظة

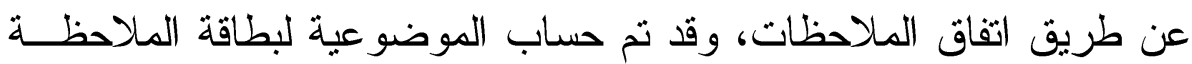
في هذه الدراسة عن طريق اتفاق الملاحظات على مدى تو افر كل معيار من ون لهن

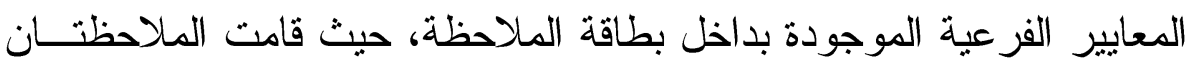

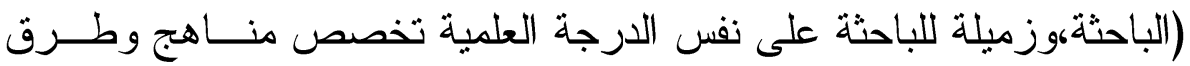

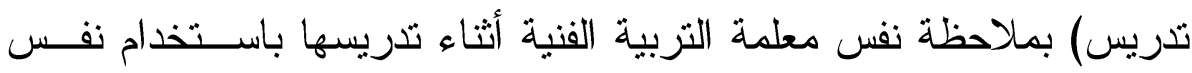
بطاقة الملاحظة، وفي فترة زمنية منساوية بحيث بدأت الملاحظتــان معسـاً

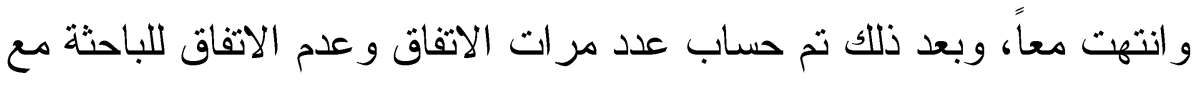
الملاحظة الأخرى حيث ثامت الملاحظتان بملاحظة عدد(10)معلمات بمنلون

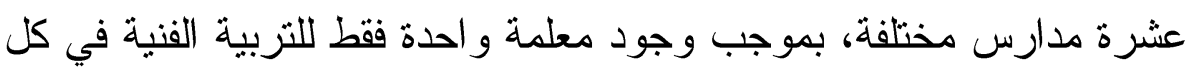
مدرسة.

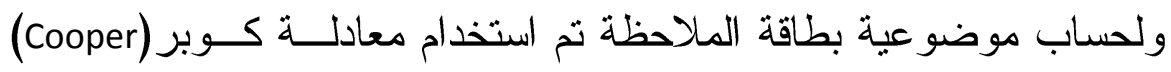
للاتفاق، وقد بلغت أعلى نسبة اتفاق بين الملاحظتين(98.87\%)، و اقل نسبة اتفاق 451 
كانت(88.87\%)، وبلغ المتوسط الحسابي لنسبة اتفــاق الملاحظتـــن (95.32\%)، و هو يعد معامل ثبات مرتفع مما يمكن الاطمئنان على مدى ثبات البطاقة وهذا

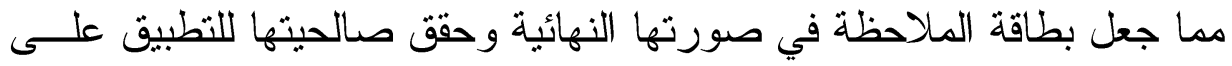
مجمو عة الدر اسة الأساسية. تطبيق أداة الدراسة (بطاقة الملاحظة) وتحليل وتفسير النتائج : * تم تطبيق بطاقة الملاحظة على عينة مكونة(30) معلمة من معلمات التربية الفنية بالتعليم العام في مدينة مكة المكرمة خلال الفصل الدراسي الأول للعام الدر اسي 1433-1434هـــ بهي.

* تحليل وتقسير نتائج تطبيق بطاقة الملاحظة: تم تصحيح بطاقة الملاحظــــة ورصد الدرجات ثم نم حساب النسبة المئوية على فئات الاستجابة للبطاقة وهي

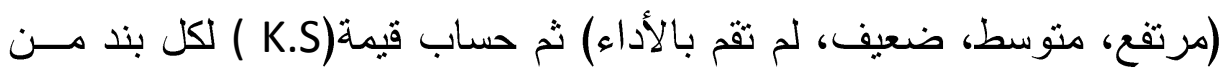

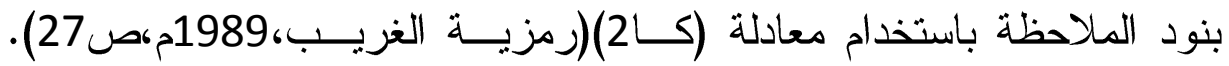

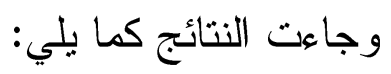
• وجود دلالة احصائية عند مستوى (0.01) لدى جميع بنود بطاقة الملاحظة

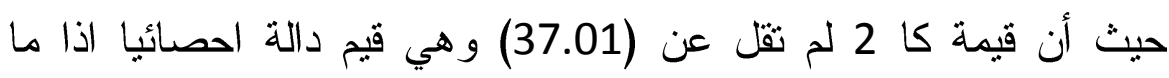
قورنت بقيمة كا2 الجدولية عند درجة حرية (2) التي تساوي (11.34).

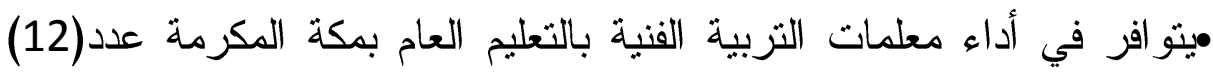
مؤشر من(120) مؤشر من المعايير المقترحة لجودة أداء معلم التربية

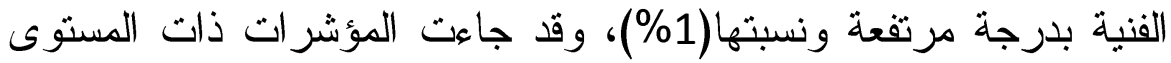

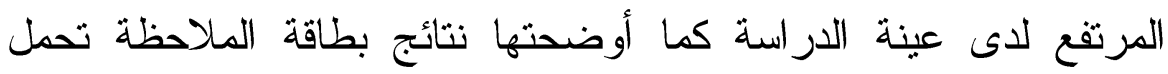
الأرقام:( 117-116-115-114-105-104-103-102-101-44-41-28 ). • يتو افر في أداء معلمات التربية الفنية بالتعليم العام بمكة المكرمة عدد (26) مؤشر من(120)مؤشر من المعايير المقترحة لجودة أداء معلم التربية

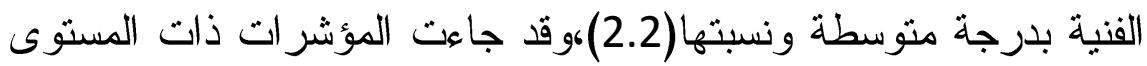


المتوسط لدى عينة الدراسة كما أوضحتها نتائج بطاقة الملاحظة تحمل

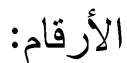

98-93-92-91-90-89-78-76-75-74-73-72-71-70-69-68-65-63-62-52-43-35-21-12-11-2) .(

هيتو افر في أداء معلمات التربية الفنية بالتعليم العام بمكة المكرمة عدد (30) مؤشر من(120)مؤشر من المعايير المقترحة لجودة أداء معلم التربية الفنية بدرجة ضعيفة ونسبتها(2.6)هو قد جاءت المؤشرات ذات المستوى الضعيف لاى عينة الدر اسة كما أوضحتها نتائج بطاقة الملاحظة تحمل الأرقام -79-77-69-66-53-47-46-45-39-38-36-29-27-24-23-19-18-17-16-13-10-4-3-1) .(108-107-106-87-86-85 • عدم تو افر بقية المعايير المقترحة لجودة أداء معلمات التربية الفنية بالتعليم العام بمكة المكرمة التي تضدنتها بطاقة الملاحظة وهي عدد(52) مؤشر من(120) مؤشر ،وقد جاءت المؤشرات ذات المستوى(لم تقم بالأداء) لدى عينة الدر اسة كما أوضحتها نتائج بطاقة الملاحظة تحمل الأرقام: -58-57-56-55-54-51-50-49-48-42-37-34-33-32-31-30-26-25-22-20-15-14-9-8-7-6-5) -118-113-112-111-100-99-97-96-95-94-88-84-83-82-81-80-70-68-67-64-61-60-59 .$(120-119$ 


\section{نتائتج (الدر (سـة:}

بناءً على أهداف الدراسة و إجر اءاتها المنهجية برزت النتائج التالية:

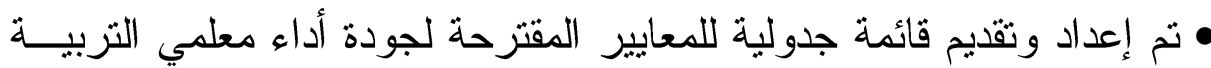
الفنية في التعليم العام بالمملكة العربية السعودية تشمل المجـــال و المعيـار

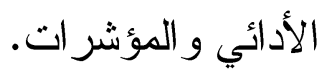

• ظهور انخفاضاً ملحوظاً في الأداء المهني لمعلمات التربية الفنــــة بــالتعليم

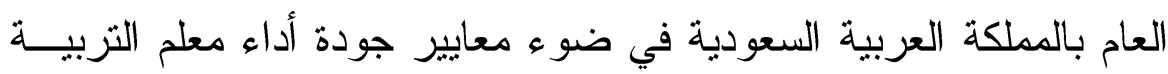

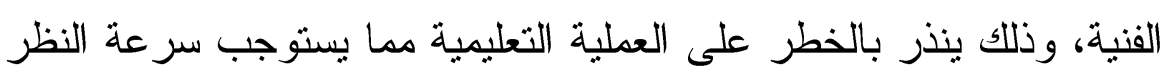

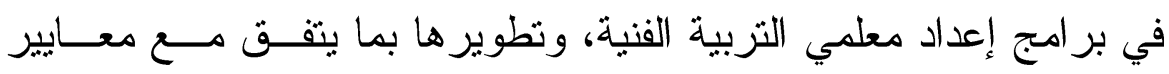
الجودة.

توصبات الارسةة: في ضو ء النتائج الني أسفرت عنها الدراسة الحالية بمكن

$$
\text { تقديم النوصيات الآتية : تونيات }
$$

تتكثيف التوعية بأهمية الجودة، والتعريف : بها من خــلال وســائل الإعـلام المختلفة.

•لاهتمام بتدريس مفاهيم ومبادئ الجودة الثـــاملة وتضـــمينها فــي المنــاهج

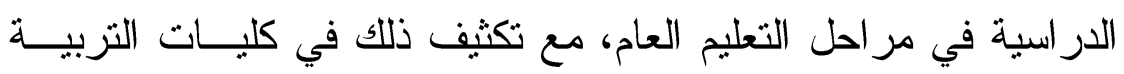
ومعاهد إعداد المعلمين.

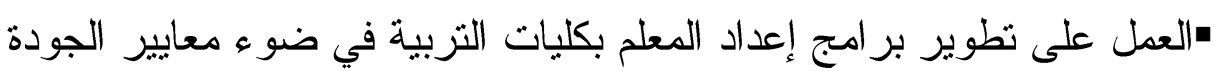

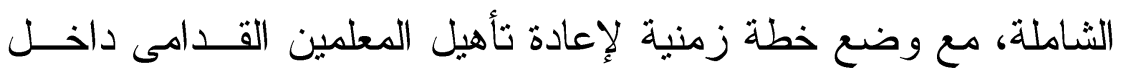
كليات التزبية أو في مر اكز التذريب على معايير الجودة الثاملة.

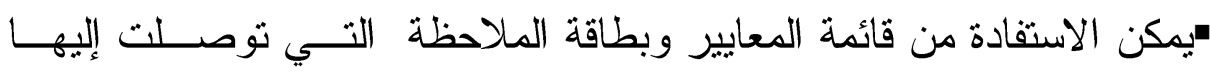
الار اسة الحالية.

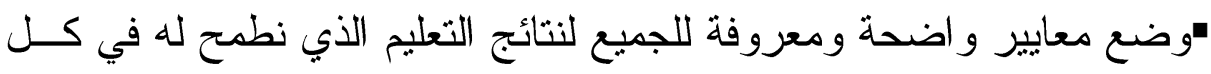
مرحلة من المر احل التعليمية، ومقارنتها بالمعايير العالمية للجودة الثاملة.

$$
\text { doi : } 10.12816 / 0004231
$$




\section{المراجيع}

أولاً : المراجع العربية

1مجمع اللغة العربية، المعجم الوسيط، ط4، مكتبة الثرق الدولية، القاهرة،

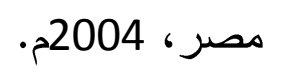

2اللجنة القومية لضمان الجودة والاعتماد، "مسودة القانون"، هيئة ضمان

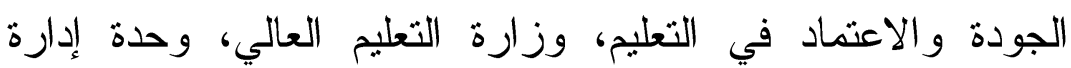

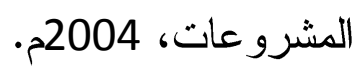

3معايير المجلس الوطني لاعتماد برامج إعداد المعلم NCATE، فبراير .2008

4إِين منظور، لسان العرب، المجلد الثاني، دار الحرية للطباعة والنشر

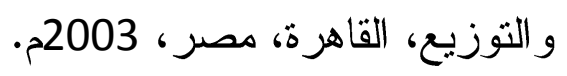

5.أحمد عايش، أساليب تدريس التربية الفنية و المهنية و الرياضية، دار المسيرة، عمان، الأردن، 2008م.

6.أحمد اللقاني و علي الجمل، معجم الدصطلحات التزبوية المعرفة في المناهج

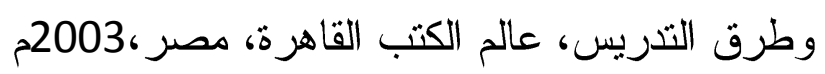

7.أحمد نصار و آخرون، المعجم الوسيط، دار إحياء التراث العربي، 2008م.

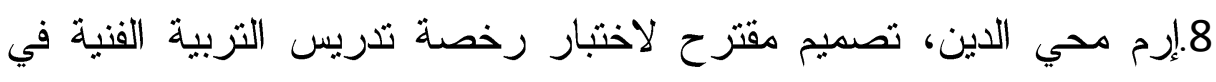

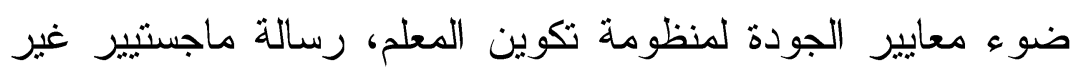

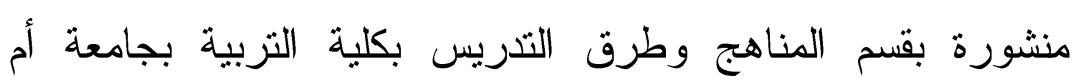

$$
\text { القرى، 2014م. }
$$

9.إيمان المريعي، تحديد معايير تقويم أداء طالبات التنريب الميداني في التربية

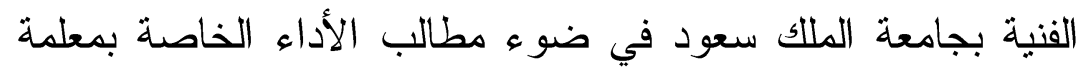
التربية الفنية باستخدام اسلوب دلفاي، جامعة الملك سعود، الرياض،

$$
\text { 2007 }
$$


10صالح آل زاير، معايير معلم التربية الفنية، الإدارة العامة للتقويم والجودة التربوية، وزارة التربية و التعليم، المملكة العربية السعودية 2012م. 11بشري العنزي، نطوير كفايات المعلم في ضوء معايير الجودة في التعليم

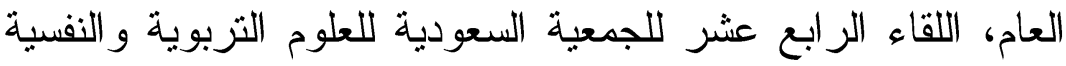

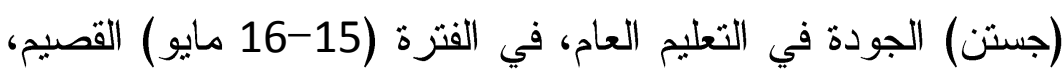

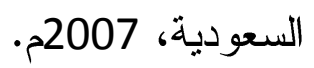

12حسني الأشقر، تطوير كفايات معلم الفنون النشكيلية في ضوده معايها، معايير

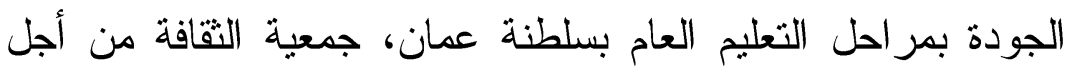

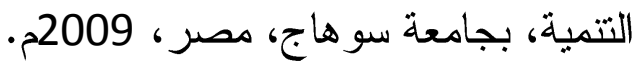
13حسن الخليفة، المنهج المدرسي المعاصر، ط5، مكتبة الرشد، الرياض، السعودية، 2005م.

14حسن شحاته وزينب النجار، معجم المصطلحات التزبوية والنفسية، الدار المصرية اللبنانية، القاهرة، 2003. 15خالد الزواوي، الجودة الثاملة في التعليم وأسواق العمل في الوطن العربي، العي، مجموعة النيل العربية، القاهرة، مصر، 2003م.

16خالدة الكيلاني، تو افق محتوى برنامج إعداد معلمي التزبية الفنية في

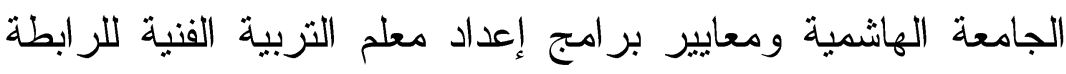

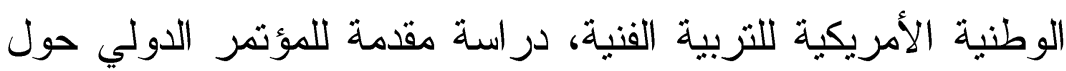

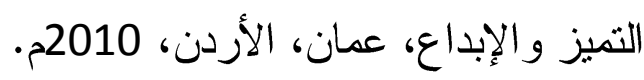
17ذوقان عبيدات وآخرون، البحث العلمي مفهومه أدواته أساليبه، دار الفكر الاردن، للنشر و النوزيع، عمان، الأردن. 18رمزية الغريب، القياس اللابرمتري في العلوم السلوكية، مكتبة الأنجلو الأودن

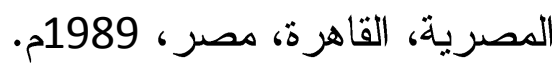


19سهيل دياب، مؤشرات الجودة في التعليم الجامعي الفلسطيني، مجلة الجودة، الجامعة الإسلامية بغزة، 2006م. مؤنرات

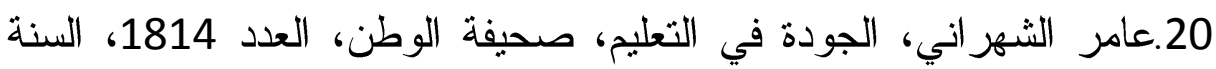

$$
\text { الخامسة، المملكة العربية السعودية، } 2005
$$

21كاظم جبر، تقويم برنامج التربية الفنية وفقاً لبعض المعايير العالمبة من لمنة

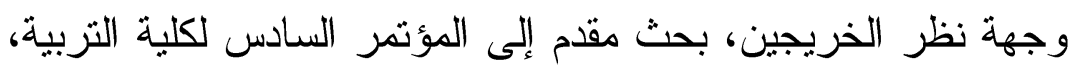

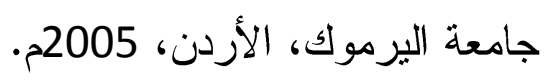

22محمود شوق ومحمــد مالك، معلم القرن الحادي و العشرين، دار الفكر الفر

$$
\text { العربي، القاهرة،مصر ، 2001م. }
$$

23محمد المغربي، الاعتماد الأكاديمي لمؤسسات إعداد المعلمين كوسيلة

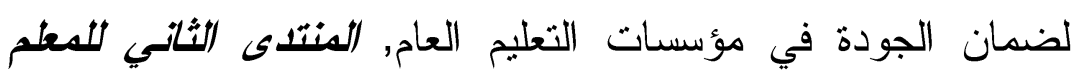

$$
\text { 2009 }
$$

24هحمد الخطيب، مدخل لتطبيق معايير ونظم الجودة الشاملة في المؤسسات التعليمية، اللقاء الرابع عشر للجمعية السعودية للعلوم التربوية

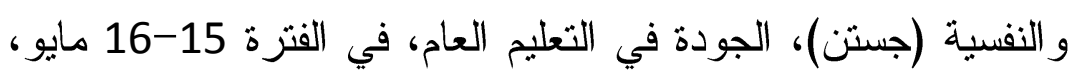

$$
\text { القصيم، السعودية 2007م. }
$$

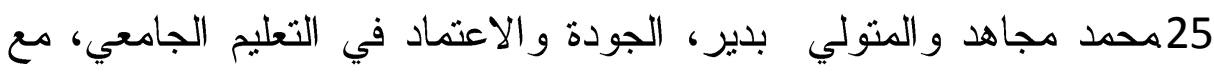

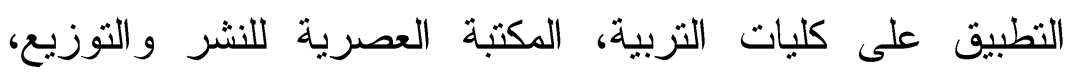

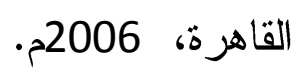

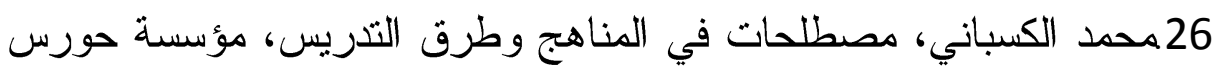

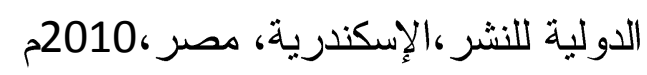

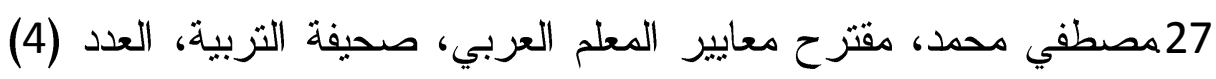

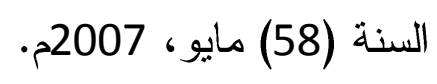


28وفاء عون، دراسة تقيميه لمدى تطبيق معايير NCATE في كلبة التربية للبنات بجامعة الملك سعود، جامعة الملك سعود، بدون تاريخ.

29.Webster New World Dictionary,1998,48.

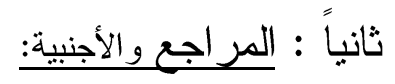

30.U. S. Department of Education, the National Endowment. )1999) Standards for Art Teacher Preparation. NATIONAL ART EDUCATION ASSOCIATION.

31.Wise.A.andlebbrand.A. Standards and teacher Quality :Entering the new Millennium, Delta Kappn 2001

32.Morgan ,C.\& Murgatroyd ,S.Total Quality management the public sector An International Perspective, Buckingham : Open University press , 1994

33.Tenner, A.R \& De Toro ,I.J. total Quality management : Three Steps to Continuous Improvement, Reading, Mass: Addison-Wesley Puplishing Co.In ,1992

34.White ,p.T \&Stephenson,A.E " Supervised Teaching Practice : System for Teacher Support and Quality Assuance, "Medical Teacher, Vol (22) No, (6) pp.604-606Noov,2002 